Çanakkale Araştırmaları Türk Yıllığı

Yll: 13, Bahar 2015, Sayı: 18, ss. 705-741, 100. Yıl

\title{
Bursalı Mehmet Nihat Bey
}

\section{Sezgin KAYA"}

$\ddot{O} z$

1886'da doğan ve 1928'de görev esnasında kaza kurşunu ile İzmir'in Güzelbahçe ilçesinin Klizman bölgesinde şehit düşen Bursalı Yarbay Mehmet Nihat Bey, 42 yıllık kısa hayatına harp tecrübelerinin yanı sıra çevirilerinin de yer aldı̆̆ı 39 harp tarihi eseri sığdırmıştır. Cumhuriyet'in ilk ve en önemli harp tarihçileri arasında yer alan Nihat Bey, asker olmanın ötesinde bir aydındır. Tarafsız bir bakış açısıyla yazdı̆̆ı eserlerinde, muharebelere ilişsin pek çok hatayı ve ders alınması gereken noktay titizlikle işlemiştir. Eserlerinin yazılması üzerinden neredeyse bir asır geçmesine rağmen araştırmacılar tarafından tam anlamiyla halen keşfedilememiştir.

Cumhuriyet'in ilk harp tarihçisi Bursalı Mehmet Nihat Bey, Trablusgarp, Balkan Harbi, Çanakkale ve İstiklâl Savaşı'na katılmıştır. Uzun yıllar Harp Akademisinde öğretmenlik yapmış ve birçok kurmay subayı fikrî yönden etkilemiştir. Cumhuriyet'in ilk ylllarında Harp tarihi içerikli konferanslar vermiş, vefatından bir yıl öncesine kadar Çanakkale'yi ziyaret edenlere, çarpışmaların geçtiği mekânlarda, çok değerli bilgiler aktarmıştır.

Nihat Bey, yaşadiğı dönem ve katıldiğı savaşlar itibarıla döneminin koşullarını objektif bir gözle analiz etmiş ve kendinden sonra gelecek nesillere büyük eserler bırakmıştır. Tanık olduğu olayları kaleme alarak yakın tarihimize ışı tutmuştur.

Anahtar Kelimeler: Balkan Harbi, Çanakkale Savaşı, Bursalı Mehmet Nihat Bey, I. Dünya Harbi

Öğ. Yzb., Maltepe Askeri Lisesi, szgnkaya@gmail.com 


\title{
Lieutenant Colonel Mehmet Nihat
}

\begin{abstract}
Lieutenant Colonel Mehmet Nihat Bey of Bursa who was born in 1886 and martyrized by a stray bullet during his military service at Klizman area of Güzelbahçe district in Izmir, accomplished to write 39 books about military history which are including his war experience and his translation works. Nihat Bey who is the first and the most important military historian in the Republic of Turkey, was an intellectual person rather than a soldier. He meticulously evaluated many mistakes and points should be learn about war by an objective eye in his works. Although Altough it past a century from the time this books had been written this great person couldn't have been totally discovered by researchers yet.

The first military historian in Republic of Turkey Mehmet Nihat Bey, participated in Trablusgarp, Balkan, Çanakkale and Turkish War of Independence. He taught in military academy for many years and he impressed many staff officers in terms of idea. During the first years of republic era in Turkey helectured about military history and until the last year before he died he had given so useful informations in warfare of Çanakkale for visitors.

Nihat Bey evaluated the conditions about the period of his life and the wars he participated by an objective view and he left great materials for next generations succeeding him. He enlightened our recent history by writing the events which he had witnessed. Studies of Nihat Bey has an important impact for the researchers who want to have knowledge about Balkan and Çanakkale wars which fullfilled their 100 th anniversary.
\end{abstract}

Keywords: The First World War, Balkan Wars, Gallipoli Front, Bursalı Mehmet Nihat Bey

\section{Giriș}

1886'da Bursa'da doğan ve 1928'de görev esnasında kaza kurşunu ile İzmir'in Güzelbahçe ilçesinde (Klizman'da) ${ }^{1}$ şehit düşen Kurmay Yarbay Bursalı Mehmet Nihat Bey, 42 yıllık kısa hayatına kendi harp tecrübelerinden (Trablusgarp, I. ve II. Balkan Harpleri, I. Dünya Harbi, Kurtuluş Savaşı) ve yabancı kaynaklardan çevirdiği 39 harp tarihi eserini sığdırmıştır. Aynı zamanda Cumhuriyet'in ilk harp tarihçisi olan Nihat Bey'in yazdığı eserler, zamanın çok ötesinde tarafsız bir kalemle ustaca yazılmış, hatalar ve ders alınması gereken noktalar titizlikle işlenmiştir. Yazdığı eserlerin üzerinden bir asır geçmesine rağmen bu büyük insan, tarihçiler tarafından henüz tam

1 Cumhuriyetin ilk dönemlerine kadar Güzelbahçe'ye Klizman denilmiştir. 
anlamıyla önemi bilinmediği söylenebilir. Hazırlamış olduğumuz makalede tarihin tozlu raflarında unutulan bu büyük insanı geniş kitlelere duyurmak için bir kuyumcu ustası titizliğinde çalıştık. Çünkü Kurmay Yarbay Bursalı Mehmet Nihat Bey hakkında tarihçilerin yayınları son derece az ve bilgi yönünden kısıtlıdır.

\section{1. Öğrenim Hayatı}

Mehmet Nihat Bey, 1886'da Bursa'da doğmuştur. Bu nedenle kendisine Bursalı denilmiştir. Babası Abdulvahap, dedesi Özbekistan'ın Buhara kentinde doğan Hacı Vikvik'tir. $^{2}$

Bursalı Mehmet Nihat Bey, 01 Kanun-i Sani 1318'de ${ }^{3}$ İstanbul'daki Kara Harp Okuluna başlamış ${ }^{4}$ ve 14 Mayıs $1321{ }^{\prime}$ de $^{5}$ teğmen olarak mezun olmuştur. ${ }^{6}$ Dereceye girmesinden dolayı aynı yıl yine İstanbul'da yer alan Harp Akademisine başlamıştır. ${ }^{7}$ Harp Akademisindeki eğitimi devam ederken 25 Şubat 1322'de [10 Mart 1907] Üsteğmen rütbesine terfi etmiştir. ${ }^{8}$

\section{Askerlik Hayatı}

Üsteğmen Bursalı Mehmet Nihat Efendi, ${ }^{9}$ 14 Teşrin-i Sani 1323'te [27 Kasım 1907] 78. Alay, 2. Tabur, 5. Bölüğe tayin edilmiştir. ${ }^{10}$ Burada iyi derecede Fransızca,

2 Nihat Bey’in Torunu Munis KİRIZMAN İle Yapılan Mülakat, Urla/İzmir, 04.12.2013.

3 14 Ocak 1903.

4 Kara Harp Okulu Cumhuriyet döneminde başkent Ankara'ya taşınmıştır.

527 Mayıs 1905.

6 Harp Okulundaki Sicil Nosu Piyade-1321-6 (1905-6)'dır. Ayrıntılı bilgi edinmek için bkz. "Kurmay Yarbay Bursalı Mehmet Nihat Bey'in Şahsi Dosyası ve Emeklilik İşlem Dosyası", T.C. Milli Savunma Bakanlığ Arşivi, Ankara.

7 Günümüzde Harp Akademisi halen İstanbul'da eğitimine devam etmektedir.

8 Bursalı Mehmet Nihat Bey'in Harp Akademisinde okuduğu 64. Dönem, özelliği olan bir sınıftı. “Bu sınıf 7 Kasım 1909'dan itibaren tamamıyla yeni yöntemler uygulanarak yetişen bir sınıftır. Ancak bu dönemin öğrencileri Trablusgarp ve Balkan Savaşları'na rastladığı için Genelkurmay Başkanlığında staj görmemiştir. Sınıfın öğrencileri peyderpey kurmay olmuşlardır. Ekim 1909’a kadar Harp Okulunda öğrenim gören kurmay subay sınıfları, bu tarihte Yıldız Sarayı Şehzadeler Dairesine taşınarak Erkan-ı Harbiye Mektebi (Harp Akademisi) adını alıp doğruca Genelkurmay Başkanlığına bağlı olarak öğrenime başlamıştır ve giriş sınavlarını kazanan iki yıl kıta hizmeti görmüş, 25 yaşını geçmemiş teğmen ve üsteğmenlerle bir defaya mahsus olmak üzere 30 yaşını geçmemiş yüzbaşılar, sınavlarda başarı kazanmak koşuluyla akademiye alınmışlardır.", 64. Dönem öğrencilerinden 7'si șehit düşmüştür. 64. Dönemden bir korgeneral (Harp Akademisinde iki kez komutanlık yapmış olan M. Kenan Dalbaşlar), iki tümgeneral (Refet Bele ve Kazım Dirik), dört albay, 3 yarbay, 8 binbaşı (3'ü şehit) ve 3 yüzbaşı (3'ü de şehit) çıkmıștır. Ayrıntılı bilgi edinmek için bkz. Nurettin Türsan, Büyük Askeri Tarih Öğretmeni Bursalı Kurmay Yarbay Mehmet Nihat Bey, Harp Akademisi Yayınları, İstanbul, 1996, s.10.; Ayrıntılı bilgi edinmek için bkz. "Kurmay Yarbay Bursalı Mehmet Nihat Bey'in ...

9 Cumhuriyetin ilk dönemlerine kadar orduda Yüzbaşı ve aşağı rütbedeki subaylara "Efendi", Binbaşı ve Albay rütbesindeki subaylara "Bey", General rütbesindekilere ise "Paşa" denilmiștir.

10 78. Alayın 2. Orduya mı yoksa bașka bir birliğe mi ait olduğu arșiv kayıtlarında rastlanamamıștır. Ayrıntılı bilgi edinmek için bkz. "Kurmay Yarbay Bursalı Mehmet Nihat Bey’in ... 
Almanca ve İngilizce öğrenmiştir. ${ }^{11}$ Mart 1325'te [1919] Adana ve havalisinde gelişen olaylar üzerine taburuyla beraber İskenderun ve Bilan bölgelerinde görevlendirilmiştir.

07 Teşrin-i Sani 1326'da [20 Kasım 1910] Harp Akademisi nizamnamesi gereğince staj eğitimi için Makedonya'da bulunan 2. Ordu, 78. Alay, 2. Tabur, 1. Bölüğe tayin edilmiştir. ${ }^{12} 6$ Mayıs 1327'de [19 Mayıs 1911] görev yaptığı birliğin adı değişmiş ve 3. Kolordu, Nizamiye 20. Alay, 1. Tabur olmuştur.

1910'da Ayşe Sıdıka Hanım'la (Kirizman) evlenmiştir. ${ }^{13}$ Aynı yıl Üsteğmen Bursalı Mehmet Nihat Efendi, stajını tamamladığı için İstanbul'a dönmüş ve Harp Akademisindeki tahsiline devam etmiştir. 01 Temmuz 1912'de hayattaki tek çocuğu Orhan doğmuştur. Ancak kendisi bu doğum hadisesi esnasında Harp Akademisi 3. sınıf öğrencisi olmasına rağmen 31 Mayıs-06 Eylül 1328 [13 Haziran-19 Eylül 1912] tarihleri arasında İtalya'ya karşı kurulmuş olan “Çanakkale Ordusu”"na ${ }^{14}$ tayin edilmiştir. Böylece Üsteğmen Bursalı Mehmet Nihat Efendi, meslek hayatındaki ilk harbi olan Trablusgarp Harbi'ne katılmış oluyordu. ${ }^{15}$

16 Eylül 1328'de [26 Eylül 1912] Balkan Harbi Seferberliği dolayısıyla Büyük Karargâh-1 Umumi Erkan-ı Harbiyesine (Başkomutanlık-Genelkurmay) tayin edilmiştir. ${ }^{16} 09$ Teşrin-i Evvel 1328'de [19 Ekim 1912] Yüzbaşı olmuş ve 19 Teşrin-i Evvel 1328'de [1 Kasım 1912] kurmaylığı onaylanmıştır. Kurmay Yüzbaşı Bursalı Mehmet Nihat Efendi, böylece Harp Akademisini 7 yılda bitirmiş oluyordu. ${ }^{17}$ Balkan Harbi esnasında Kurmay Yüzbaşı Bursalı Mehmet Nihat Efendi, Türk ordusunun eksikliklerini ve hatalarını yakından takip ederek ileride yetişecek subayların, yapılan hatalardan ders alabilmesi için kendince harp tarihi raporları tutmaya başlamıştır. Gördüğü hataları dönemin şartlarından sıyrılarak tarafsız bir gözle yazdığı için hatalı hareket eden üstleri tarafından sevilmeyen, doğru hareket eden üstleri tarafından ise çok sevilen bir insan olmuştur. ${ }^{18}$ Kurmay Yüzbaşı Bursalı Mehmet Nihat Bey’in bir özelliği

11 Yabancı dili eser çevirecek kadar iyi olduğu için birçok harp tarihi eserini ülkemize kazandırmıştır. Bkz. "Eserleri” kısmına ve bu eserlerden örnekler için ise Ekler Bölümü Ek 8-9.

12 Üsteğmen Bursalı Mehmet Nihat Efendi'nin staja gönderildiği 78. Alay'ın 2. Ordu'ya bağlı olduğu bilgisine ulaşılmıştır. Ayrıntılı bilgi edinmek için bkz. “Kurmay Yarbay Bursalı Mehmet Nihat Bey’in ....

13 Kurmay Yarbay Bursalı Mehmet Nihat Bey’in ailesi ile çektirmiş olduğu fotoğraf için bkz. Ekler Bölümü Ek 1.

14 Çanakkale Ordusu, Trablusgarp Harbi sırasında güç durumda kalan İtalya'nın Osmanlıyı barışa zorlamak için donanması ile İstanbul'u tehdit etmek istemesi üzerine kurulmuştur. Bu ordunun görevi Çanakkale Boğazı'nı korumak ve düşmanı boğazdan geçirmemekti. Çanakkale Ordusu'nun kuvveti ise 6 fırkadan oluşan 2 kolordudan ibaretti. Ayrıntılı bilgi edinmek için bkz. Cemalettin Yıldız, Bir Komutanın Gözünden Çanakkale Savaşları, Emre Basımevi, Çanakkale, 2007, s. 21.

16 "Kurmay Yarbay Bursalı Mehmet Nihat Bey'in ...

17 64. Dönemden önceki dönemler Harp Akademisini 3 yılda bitiriyorlardı.

18 Kurmay Yarbay Bursalı Mehmet Nihat Bey'in 1928'de şehadetinden kısa bir süre önce yazdığı ve en büyük telif eseri olan Balkan Harbi, 1328-1329” Trakya Seferi (Lüleburgaz Meydan Muharebe- 
de sadece Türk ordusunun manevraları ve hatasını değil, düşman unsurların faaliyetlerini de tarafsız bir gözle yazmasıdır. Yazmış olduğu raporların bir kısmı sonradan kitap olarak Osmanlıca basılmıştır. ${ }^{19}$ Günümüzde tarih anlayışının gelişmesiyle araştırmacılar, Balkan Savaşları'na ve Çanakkale Harbine ait ayrıntılı bir biçimde kaynak incelemesine başlamıştır. Bu vesileyle Bursalı Mehmet Nihat Bey’in yazmış olduğu eserler tanınmaya başlamıştır.

Genç Kurmay Yüzbaşı Mehmet Nihat Efendi, Balkan Harpleri sonunda henüz 1 yıl önce Harp Akademisinden mezun olmasına rağmen, yeteneği ve kabiliyeti dikkati çektiğinden 09 Teşrin-i Evvel 1329'da [22 Ekim 1913] Kara Harp Okulu'na “Harp Tarihi” ve "Coğrafya” Öğretmen Vekilliğine tayin edilmiştir. ${ }^{20}$

I. Dünya Harbi öncesi Kurmay Yüzbaşı Bursalı Mehmet Nihat Efendi, 02 Kanun-i Sani 1329'da [15 Ocak 1914] Karargâh-1 Erkân-1 Harbiye Umumiye Dairesi 1. Şubeye tayin edilmiştir. 26 Mayıs-15 Haziran 1330 [8-20 Haziran 1914] tarihleri arasında Topçu Atış Okulu Küçük Ümera Kursu'na katılmıştır. 21 Temmuz 1330 [3 Ağustos 1914] Seferberliğinde Karargâh-1 Umumi 1. Şubeye tayin edilmiştir. Bu görev esnasında 25 Şubat 1331'de [10 Mart 1915] Kıdemli Kurmay Yüzbaşı rütbesine terfi etmiştir. ${ }^{21}$

15 Mart 1331'de [28 Mart 1915] Çanakkale'de Truva yakınlarındaki Kalvert Çiftliği'ndeki ${ }^{22}$ 15. Tümen'e Harekât Şube Müdürü, olmuştur. Kıdemli Kurmay Yüzbaşı Bursalı Mehmet Nihat Efendi, 12 Nisan 1331'de [25 Nisan 1915] yaşadığı sıcak çatışmayı şu şekilde yazmıştır:

Pazar günü saat sabah 05.00’ten önce, birdenbire şiddetli top sesleri ile uyandık. Henüz alacakaranlıkt. Bu sirada bende 15. Tümen'in 1. Şube Müdürü olarak Anadolu tarafinda Kalvert çiftliğinde idim. Fırkaların durumunda değişiklik olmadığını, 3. Fırka boğaza 27 harp gemisinin girdiğini bildirdi. İlk duygu yine bir deniz hücumu başladĭ̆ı merkezinde idi. Ancak sabah saat 10.00’a doğru 15.

si) adlı eserinin 3. Cildi (Karargâh-1 Umumi Darülharekatta-Lüleburgaz Meydan Muharebesi)'nin "Başlangıç" (önsöz) kısmında verdiği şu bilgiler manidardır. "Söze son vermeden şunu da eklemeyi gerekli görürüm: Bu ciltte de beni iten içtenlik ve iyi niyettir. Kendimce yanlış gördüğüme yanlış, kötü saydığıma kötü dedim. Hüküm ve kanaatlerimin kişilerle ilişkisi yoktur. Harekât ve muharebelerden sorumlu olan komutan ve kişilerin içinde kişisel olarak tanıdığım ve tanımadığım da vardır. Hepsinin yurtseverliği, kişisel değerleri, çaba ve fedakârlığ söz ve kuşku götürmez. Nitekim içlerinde, bu savaşta aldı̆̆ı derslerle Büyük Harp'te, İstiklal Muharebeleri'nde yüksek nitelik göstererek Tanrinın hakkına kavuşmuş ya da hâlen hayatta olan birçok kişi vardır. Dolayısıyla hafif ya da sert eleştiri ve düşünceler filana değil, ancak Balkan Harbi’nde filan gün, filan kıtanın başında bulunan kişiliklere yöneliktir. Öte yandan bu düşüncelerimde, elbet, hatasız, olamayacağım gibi elime geçirmiş bir belgenin ortaya çıkmasıla da görüşlerimin kısmen ya da tamamen değișmeye mahkûm olabileceği de açıktır. Yeter ki gerçek belirlensin..." Ayrıntılı bilgi edinmek için bkz. Yarbay Mehmet Nihad, Balkan Harbi-1328-1329 Trakya Seferi (Lüleburgaz Meydan Muharebesi), c. 3, Askerî Matbaa, İstanbul, 1928.

19 Kurmay Yarbay Bursalı Mehmet Nihat Bey'e ait eserler için bkz. Eserleri kısmına ve bu eserlerden örnekler için ise bkz. Ekler Bölümü Ek 2, 3, 4.

20 “Kurmay Yarbay Bursalı Mehmet Nihat Bey'in ....

21 “Kurmay Yarbay Bursalı Mehmet Nihat Bey'in ...

22 Şimdiki Taştepe Köyü yakınlarındaki TİGEM’in olduğu yer. 
Tümen, Kabatepe ve Seddülbahir taraflarına çıkarma yapıldı̆̆ını, boğazda bir deniz muharebesi olmadı̆̆ını haber aldı. Ve daha garibi ancak öğleye doğru düşmanın Kumkale'ye de Fransız askeri çıkardiğı anlaşılabildi. Seddülbahir güneyinde çeşitli düşman harp gemileri öğleye kadar öteye beriye mermi savurmuş, başka bir olay olmamıştı. Şu olay bize Anadolu tarafindaki gözetleme tedbirlerinin ve muharebe işlerinin iflasını bildiriyordu. Sonradan anlaşıldığına göre firkaların elindeki toplam 15-20 km.lik tel ve kablo ile kurulan açık asma telefon hatları ilk bombardımanda kopmuş, Kumkale'deki gözetleme birlikleri ilk düşman baskısının altında ezilmiş ve geriye haber göndermek ya akla gelmemiş ya da gönderememiștir.

Bunun üzerine 15. Tümen ve 3. Firka bu gece Kumkale’ye taarruz edilerek düşmanın mutlaka geri püskürtülmesini emretti... 26-27 Nisanda düşman bu bölgeden püskürtüldü. ${ }^{23}$

Anadolu tarafında düşman tehlikesi kalmayınca Kıdemli Kurmay Yüzbaşı Bursalı Mehmet Nihat Efendi, 15 Nisan 1331'de [28 Nisan 1915] Gelibolu'da bulunan Seddülbahir Mıntıkası Erkan-ı Harbiyesine gönderilmiş ve birkaç gün sonra Cenup (Güney) Grubu 1. Şube Müdürlüğü görevine tayin edilmiştir. ${ }^{24}$ Bursalı Mehmet Nihat Efendi, kendisine verilen görevleri icra ederken kimseden çekinmeyerek gördüğü hataları düzeltmesi için yaptığı uyarılar üstlerinin hoşuna gitmese de, zamanla haklı olduğu görülünce büyük bir saygınlık kazanmaya başlayacaktır. Bu duruma en güzel örnek Cenup Grubu 1. Şube Müdürlüğü esnasında yaşadığı şu hadise verilebilir:

"Bu geceki taarruza katılma emrini alan 15. Tümen Komutanı saat 17.00'de Bölge Komutanlığı karargâhına geldi. Karargâh, bir tepenin eteğinde küçük bir eski cephanelikti. Komutan tümeninin ancak 21.00'de cephe gerisine yanaşabileceğini bildirdi.

Almanlar bir sakınca görmediler. Taarruz bundan iki saat sonra, saat 23.00'te başlayacaktı. Komutana harita üzerinde savaş düzenini ve görevi anlattılar:

"Tümenimiz cephenin doğu kesiminde yer alacak, Fransız cephesini yararak ilk aşamada Morto Koyu sırtlarını ele geçirecek, bu kesimde bulunan Fransızları yok edecek, sonra batıya, Ingilizleri de son erine kadar temizleyecek."

İki Kurmay Albay ile bir Kurmay Binbaşının, üç Almanın kafa kafaya vererek yaptığı plan buydu. 8.000 kişilik 15. Tümenden, Seddülbahir'e çıkmış ve yerleşmiş bütün düşmanı yok etmesi isteniyordu.

Bu hayalci, hesapsız plan Yüzbaşı Mehmet Nihat'ın (Bursalı Mehmet Nihat Efendi) kanını dondurdu.

23 Ayrıntılı bilgi edinmek için bkz. Yıldız, Bir Komutanın Gözünden ..., s. 32 vd.

24 Ayrıntılı bilgi edinmek için bkz. "Kurmay Yarbay Bursalı Mehmet Nihat Bey’in ... 
15. Tümen Komutanı Albay, nazik biriydi. Tartışma açmadı. İtiraz etmedi. Düşmanının gücünü sormadl. Belki Almanlara güvendi, belki telaştan söylenenleri iyi anlamadı. "Hay hay, tamam, olur" gibi yanıtlar vererek tümeninin zamanında gelmesini sağlamak için karargâhtan ayrıldı.

Yüzbaşı Mehmet Nihat, Tümeni olası bir felaketten kurtarmak ümidiyle Albay Von Sodenstern'i uyarmaya çalıştı, Tümeninin dinlendirilmesi ve bir gece taarruzunun gerektirdiği ön hazırlıkların yapılması için taarruzun hiç olmazsa bir gün sonraya ertelenmesini önerdi ama sustular:

"Düşmana daha fazla vakit kazandırmak doğru değil. Bu gece taarruz edilecek!"

Saat 19.00'da Bölge Komutanı kesin taarruz emrini verdi. Taarruz gece 23.00'te başlayacaktı.

Bunca soruna, yoksunluğa karşı taarruzda ısrar edilmesi birliklerde tepki uyandırdı. Henüz son iki günün yaraları sarılamamıştı. Liman Paşa'ya ve Üçlüye küfrü bastılar..."

Beklenen sonuç maalesef gerçekleşerek birçok vatan evladı harman zamanı kesilen ekinlerin başakları gibi toprağa düşerek şehit olacaktır. Çanakkale Cephesinde yapılan harplere ilişkin en değerli bilgiler kuşkusuz, Bursalı Mehmet Nihat Bey, yazmıştır. Kendisi yaşananları şöyle ifade etmektedir: ${ }^{26}$

"Siperler muharebede derin birer mezbaha hâlindeydi... Bombardiman o kadar güçlü olurdu ki bu ateşin altında ileri hatlarda canlı insan kalacă̆ına ihmal verilmezdi."

Bursalı Kıdemli Yüzbaşı Mehmet Nihat Efendi, 03 Temmuz 1331'de [16 Temmuz 1915] 6. Fıkra Erkan-1 Harbiyesine tayin edilmiştir. Bu Fırka ile birlikte Saroz Körfezi ve Anafartalar Bölgesinde görev yapmıştır. Göstermiş olduğu başarılardan dolayı Kurmay Albay Mustafa Kemal (Atatürk) kendisine takdirname vermiştir. 21 Kanun-i Evvel 1331'de [3 Ocak 1916] Firkasıyla birlikte Tekirdağ'a gitmiştir. ${ }^{27}$

01 Mart 1332'de [14 Mart 1916] 13. Kolordu Nizam-1 Harbine iştirak etmek için Tekirdağ'dan Resulayn'a birliğiyle birlikte hareket ederek Hanekin ve İran Harekâtlarına katılmıştır. ${ }^{28} 01$ Eylül 1332'de [14 Eylül 1916] Binbaşı rütbesine terfi

25 Genelkurmay Başkanlığı ATASE Arşivi, Çanakkale 22, s. 381 vd.; ayrıca Turgut Özakman, Diriliş̧ Çanakkale 1915, Bilgi Yayınevi, İstanbul, 2011, s. 352 vd.

26 Kurmay Yarbay Bursalı Mehmet Nihat Bey, Büyük Harpte Çanakkale Seferi, İlhami Fevzi Matbaası, İstanbul, 1926.; Raif Kaptanoğlu, http://bursazamandergisi.com/yazarlar/bursanin-kinali-kuzulari-2057.html, 16.01.2014.

27 "Kurmay Yarbay Bursalı Mehmet Nihat Bey'in ...

28 Kurmay Yarbay Bursalı Mehmet Nihat Bey’in katıldığı seferler ve bu seferler esnasında tuttuğu harp 
etmiştir. 20 Mart 1333'te [20 Mart 1917] Cebel-i Hamrin Muharebesine katılmıştır. ${ }^{29}$

Kurmay Binbaşı Bursalı Mehmet Nihat Bey, 29 Haziran 1333'te [29 Haziran 1917] Kafkas Grubu 1. Şube Müdürlüğüne, 03 Ağustos 1334'te [03 Ağustos 1918] Genel Karargâh Kurmay Vekilliğine tayin olmuştur. ${ }^{30}$ Bu görevini sürdürürken üstün askerî stratejisinden dolayı 30 Eylül 1918'de İstanbul'da Yıldız Sarayı'nda bulunan Harp Akademisi Müdür Yardımcılığı'na da atanmıştır. Harp Akademisi ile ilgisi sürmek koşuluyla Aynı yıl Erkânı Harbiye, 16. Şubede (Tarihi Harp) görevlendirilmiş ve daha sonra Genelkurmay 3. Şube Müdür Yardımcılığı, Veliaht Şehzade Ömer Faruk Efendi'nin Öğretmenliği ve Harp Akademisi Öğretmenliği görevlerinde bulunmuştur. $^{31}$

Kurmay Binbaşı Bursalı Mehmet Nihat Bey, I. Dünya Savaşı esnasında iyi bir subay olmanın yanında bir öğretmen titizliği içinde hem savaştaki askerî stratejiler ve harekâtlarla ilgili eserler yazmış hem de I. Dünya Savaşı ile ilgili yabancı harp tarihçilerin eserlerini Türkçeye çevirerek ülkemize kazandırmıştır. ${ }^{32}$ Öyle ki bu eserler gelecek kuşaktaki subayların aynı hataları tekrarlamaması için büyük dersler içiren ana kaynak olmuştur.

Mustafa Kemal (Atatürk) Paşa, 19 Mayıs 1919'da Samsun'a çıkarak başlattı̆̆ı Millî Mücadele'ye birçok gönüllü subay gibi Kurmay Binbaşı Bursalı Mehmet Nihat Bey'de katılmak istemiştir. Bunun için Mustafa Kemal Paşa'dan izin istemesi üzerine kendisine şu haber gönderilecektir;

"Bursalı Binbaşı Mehmet Nihat Bey gibi değerli bir zabitimizin Anadolu'ya geçmemesi gerekir. Millî Mücadele'de savaşacak düzenli ordunun, eğitim görmüş tecrübeli kurmaylara daha çok ihtiyacı vardır. Böyle kıymetli zabitimizin İstanbul'da kalarak Harp Akademisinde yetiştireceği öğrencilerini Anadolu'ya göndermesi daha faydalı olacaktır."33

Mustafa Kemal Paşa, Yunanlıları Anadolu'dan atmak için Doğu ve Güney cephelerindeki kuvvetleri, Kocaeli bölgesindeki kuvvetleri Büyük Taarruzdan önce bir noktaya toplamaya başlayacaktır. Harp tecrübesi olan değerli komutanlara ihtiyaç

tarihi notlarını I. Dünya Harbi'nin akabinde eser olarak yayınlayacaktır. Ayrıntılı bilgi edinmek için bkz.: 13'üncü Kolordu'nun İran Seferi, Askerî Matbaa, İstanbul, 1920.; "Irak Cephesi Muharebatından”, Местиa-i Askeriye, Sayı: 15-16, İstanbul, 1 Haziran- 1 Temmuz 1920.

“Kurmay Yarbay Bursalı Mehmet Nihat Bey'in ....

30 "Kurmay Yarbay Bursalı Mehmet Nihat Bey’in ...; M. Şahin Aldoğan, "Bursalı Mehmet Nihat Bey, Unutulan Türk Büyüğü”, NTV Tarih Dergisi, Sayı 15, İstanbul, Nisan-2010, s. 67.

31 "Kurmay Yarbay Bursalı Mehmet Nihat Bey'in ...

32 Kurmay Yarbay Bursalı Mehmet Nihat Bey'e ait örnek eserler için bkz. Ekler Bölümü Ek 5, 6, 7, 8.

33 Bursalı Mehmet Nihat Bey'in Torunu Munis KİRIZMAN İle Yapılan Mülakat, Urla/İzmir, 04.12.2013. Nihat Bey'in Mustafa Kemal ATATÜRK ile birlikte olduğu fotoğraf için bkz. Ekler Bölümü Ek 9.; 
duyduğu için Kurmay Binbaşı Bursalı Mehmet Nihat Bey'inde Anadolu'ya geçmesini ister. Böylece 03 Mayıs 1338'de [3 Mayıs 1922] Büyük Taarruz'dan önce Mehmet Nihat Bey, Anadolu'ya geçmiş ve 6. Kolordu Kurmay Başkanı görevine tayin edilmiştir.

Başkomutanlık Meydan Muharebesi'nden bir gün sonra 31 Ağustos 1338'de [31 Ağustos 1922] Yarbay rütbesine terfi etmiş ve İstiklâl Madalyası almaya hak kazanmiştır. ${ }^{34}$

Kurtuluş Savaşı'ndan sonra 17 Teşrin-i Evvel 1338 - 07 Mayıs 1339 [17 Ekim 1922 - 07 Mayıs 1923] tarihleri arasında Balıkesir'de bulunan 2. Ordu Kurmay Başkanlığını, 07 Mayıs - 19 Ağustos 1339 [07 Mayıs - 19 Ağustos 1923] tarihleri arasında Genelkurmay Talim Terbiye Şubesi Müdürlüğü görevlerini yürütmüştür. ${ }^{35}$

Cumhuriyet döneminde ise Kurmay Yarbay Bursalı Mehmet Nihat Bey, sırasıyla: 29 Ağustos 1339 [29 Ağustos 1923]- 06 Şubat 1926 yılları arasında Harp Akademileri Harp Tarihi Öğretmenliği ve Genelkurmay Neşriyat Şube Müdürlüğü yapmıştır. ${ }^{36}$

1926’da I. Dünya Savaşı ve Kurtuluş Savaşı'nda ülkesi için şehit düşen vatan evlatlarına şehitlikler yapmak için Mustafa Kemal (Atatürk)'in emriyle "Şehitleri İmar Cemiyeti” (Türk Şehitlikleri İmar Vakfi) kurulmuştur. Bugün halen faal olan yurdumuzda birçok şehitliği imar eden ve yüzlerce şehit çocuklarının eğitim masraflarını karşılayan bu derneğin kurucu üyeleri arasında Bursalı Yarbay Mehmet Nihat Bey de yer almıştır. ${ }^{38}$ Aynı yıl Bursalı Yarbay Mehmet Nihat Bey, Atatürk’ün emri üzerine Çanakkale Cephesindeki harplerin milletimiz tarafından unutulmaması ve yaşananları objektif bir biçimde yazılarak, gelecek nesillerin hadiselerden ders alması için bir eser yazmıştır. 1926'da Kurmay Yarbay Bursalı Mehmet Nihat Bey, "Büyük Harpte Çanakkale Seferi" adlı eserini yazarak "Şehitleri İmar Cemiyeti”ne teslim etmiştir. Cemiyetin 1926'daki ilk yayınladığı ve Atatürk'e sunduğu çalışma bu eser olmuştur. Kurmay Yarbay Bursalı Mehmet Nihat Bey, Büyük Harpte Çanakkale Seferi adlı eserini çok titizlikle yazmıştır. Eserde: Savaşın nedenlerini, boğazın coğrafi konumunu,

34 “Kurmay Yarbay Bursalı Mehmet Nihat Bey'in ...; Ayrıca bkz. Ekler Bölümü Ek 22.

35 "Kurmay Yarbay Bursalı Mehmet Nihat Bey'in ...

36 "Kurmay Yarbay Bursalı Mehmet Nihat Bey’in ...; Nurettin Türsan, Büyük Askeri Tarih Öğretmeni Bursalı Kurmay Yarbay Mehmet Nihat Bey, Harp Akademisi Yayınları, İstanbul, 1996, s. 22 vd.; Ayrıca söz konusu görevler esnasında Kurmay Yarbay Bursalı Mehmet Nihat Bey'in 1924 yılına ait fotoğrafı için bkz. Ekler Bölümü Ek 10.

37 Mustafa Kemal Atatürk'ün cemiyetin faaliyetinden dolayı Cemiyet Başkanı Diyarbakır Milletvekili İbrahim Tali Bey nezdinde cemiyet üyelerine (Kurmay Yarbay Bursalı Mehmet Nihat Bey, eski İstanbul Saylavı Ziya, Süleyman Nazif, eski İstanbul Merkez komutanı General Şakir, İstanbul Müftüsü Fehmi, İtfaiyeci Ziya, tüccar Cemal Menoğlu, Yüzbaşı Naci, tüccar Tülbent Ali Haydar Muhittin, Muallim Kemal, Yüzbaşı Hulisi, Esat Serezli, Ekrem Fazıl, Osman Nuri, Muallim Ali Fırat) teşekkür ettiği telgraf haberi için bkz. Vakit, 18 Eylül 1927.; Ayrıca cemiyet hakkında ayrıntılı bilgi edinmek için bkz.:Www.tsiv.org.tr 28.02.2014.

38 Cemiyet hakkında ayrıntılı bilgi edinmek için bkz. Mithat Atabay, Mustafa Kemal'in Himayelerinde Şehitlikleri İmar Cemiyeti Nasıl Kuruldu? Nasıl Gelişti?, Türk Şehitlikleri İmar Vakfı Yayınları, İstanbul, 2012, s. 5 vd. 
Anadolu ve Gelibolu Yarımadasının arazi arızalarını, Türk ve İtilaf devletlerinin kuvvetlerini, hangi araziye yerleştiklerini, iki tarafın savaş planlarını, 18 Mart 1915'teki deniz savaşını, 25 Nisan 1915'ten itibaren başlayan kara muharebelerini (Kumkale, Sedülbahir, Arıburnu ve Anafartalar) iki tarafın savaş teknolojilerini ve savaş sonucundaki tarafların kayıplarını ayrıntılı bir biçimde yazmıştır. Eserin önsözünde Nihat Bey, şu sözleri Önsöz'de dile getiriyor.: ${ }^{39}$

"Şehremeni

15 A Ăustos 1926

Her sene Çanakkale Şehitliği’nin -ki bütün olarak Gelibolu Yarımadası ve boğazın Anadolu sahilindeki arazinin önemli bir kısmı, bizim için başlı başına bir tek şehitlikten ibarettir-ziyareti önemli bir millî ve vatanî görev sayllmakla yüksek bir değerbilirlik gösteren Şehitlikleri İmar Cemiyetinin bu davetine katılmakla aynı suretle ilmî, millî ve vatani görevi yerine getiren ve getirecek olan kişiler için Çanakkale Seferi'nin genel gelişimini anlatacak kısa bir kitap yazllması emrini alınca, itiraf ederim ki, başlı başına çok önemli bir tarih safhası olan bu seferin gelişim tarzını bir program ve fihrist halinde dahi böyle birkaç sayfaya nasıl sığgl rabilirim endişesiyle çok zor bir vaziyette kaldım. Nihayet bana bu kitabı yazma cesareti veren sebep, seferin henüz yakın olan bir geçmişte yapılmış olması ve birçok canlı şahidinin henüz hayatta bulunması oldu. Eserin kusur ve eksiklerini bu şanslı şahitler elbette tamamlar ve affederler."

Kurmay Yarbay Bursalı Mehmet Nihat Bey, 06 Şubat 1926 - 08 Temmuz 1927 tarihleri arası 13. Kolordu, 1. Fırka, 5. Alay Komutanlığı görevlerinde bulunmuştur. ${ }^{40}$ İstanbul ve Çanakkale'de Harp Tarihi ile ilgili konferanslar da vermeye başlamıştır.

09 Temmuz 1927'de son görev yeri olan İzmir Müstahkem Mevzi Mevki Piyade Liva Komutanlığı'na (Tugay Komutanı) atanmıştır. Ailesini yanına alarak İzmir Karşıyaka’ya yerleşmiştir. Torunu Emekli Binbaşı Munis Kirizman'ın babaannesinden ve babasından duyduğu bilgilere göre;

"Her sabah evinden çıkarak, Karşıyaka iskelesinden motorla Konak yakasına geçip, Sarıkışla'ya giden ve Urla'da bulunan Menteş bölgesindeki askerî tatbikatları takip eden Kurmay Yarbay Bursalı Mehmet Nihat Bey, akşam yine aynı yolla evine geri dönmektedir. Haziran 1928'de Mustafa Kemal Atatürk'ün, Afganistan Kralı Amanullah Han ile yapmış olduğu müzakere sonucu Türkiye'den Afganistan'a kıymetli subay, öğretmen ve doktorun gönderilerek bu dost ülkeyi

39 Bursalı Mehmed Nihad, Büyük Harpte Çanakkale Seferi, (çev. Elif Berfin - haz. Murat Karataş), Türk Şehitlikleri İmar Vakfi, İstanbul, 2012, s.15.

40 "Kurmay Yarbay Bursalı Mehmet Nihat Bey'in ... 
kalkındırması hedeflenmiştir. ${ }^{41}$ Afganistan'a gönderilecek subaylar arasında Kurmay Yarbay Bursalı Mehmet Nihat Bey'de vardı. Temmuz ayının ilk haftası bu bilgi kendisine geldiği zaman taşınmak için eşyalarını toplamaya başlamıştır. Ancak Urla'dan bir gece, tatbikat dönüşü nöbetçi jandarma eri tarafindan atılan bir kaza kurşunuyla 14 Temmuz 1928'de şehit düşerek o akşam evine dönemeyecektir. Acı haberi Karşıyaka'da eșini merakla bekleyen Ayşe Sıdıka Hanım ile 16 yaşındaki oğlu Orhan'a ulaşacaktır." ${ }^{\prime 2}$

3. Bursalı Mehmet Nihat Bey'in Katıldığı Savaşlar-Aldığı Nişan, Madalya ve Aldığı Takdirnameler ${ }^{43}$

\section{a-) Katıldığı Savaşlar:}

- Trablusgarp Savaşı : 31.05/06.09.1328 [13 Ağustos-19 Kasım 1912]

- Balkan Savaşı : 18.09.1328/02.11.1329 [1 Aralık 1912-15 Ocak 1914]

- I. Dünya Savaşı : 28 Mart 1915-03 Ağustos 1918

- İstiklal Savaşı : 30.05.1338/30.08 1339 [30 Temmuz 1922-30 Ekim 1923]

b-) Aldığı Nişan, Madalya ve Takdirnameler:

- Muharebe Gümüș İmtiyaz Madalyası

- Harp Madalyası 03 Temmuz 1331 [16 Temmuz 1915]

- Çanakkale'de Kurmay Albay Mustafa Kemal'in (Atatürk'ün) Takdirnamesi

- Alman Muharebe Gümüş Liyakat Madalyası

- 2. Rütbeden Alman Demir Salip Nişanı

- Bronşvilt Grant Dükalığı Harp Nişanı

- 3. Rütbeden Avusturya Liyakat Madalyası

- 3. Rütbeden Kılıçlı Mecidiye Nişanı

- İstiklal Madalyası (Madalya Numarası: S-1019 Numaralı İstiklal Madalyası ile taltif edilmiştir.)

41 Aliye Yılmaz, "Amanullah Han'ın Islahatları ve Atatürk", SDÜ Fen Edebiyat Fakültesi Sosyal Bilimler Dergisi, Sayı:21, Isparta, Mayıs 2010, s. 163 vd.

42 Bursalı Mehmet Nihat Bey'in Torunu Munis KIRIZMAN ...

43 Kurmay Yarbay Bursalı Mehmet Nihat Bey'in ... 


\section{Bursalı Mehmet Nihat Bey'in Modern Anlamda Cumhuriyetin İlk Harp Tarihçisi Olma Hadisesi}

Osmanlıda, harp tarihi zaman içinde gelişerek Bursalı Mehmet Nihat Bey'in dönemine intikal etmiştir. Bu başlık altında Osmanlıda harp tarihinin gelişme süreci ve Bursalı Mehmet Nihat Beyin neden modern anlamda Cumhuriyetin ilk harp tarihçisi olarak nitelendirildiği incelenmiștir.

II. Mahmut döneminde 1826 'da Yeniçeri Ocağı kaldırılınca Askerî Mansure-i Muhammediye ordusu kurulmuştur. Avrupa'nın en güçlü kara ordusu olan Fransız ordusunu, Osmanlı yeni kurulan orduya örnek almıştır. Ancak Fransız ordularının 1870-1871 Sedan Savaşı́nda Alman ordularına yenilmesinden sonra, Osmanlı Erkânı Harbiyesi, II. Abdülhamit dönemi (1882) bir süre tereddüt ettikten sonra yönünü Alman ordularına çevirmiștir. Osmanlı Erkânı Harbiyesi, II. Abdülhamit'in de onayıyla Alman İmparatorluğu'nun Başbakanı Bismark'tan askerî uzmanlar istemiş̦tir. 1882'de çeşitli ordu sınıflarına mensup yüksek rütbeli subaylardan kurulan bir Alman heyeti İstanbul'a gelmiştir. Heyetin başkanı Süvari Albay Köhler; üyeleri Süvari Binbaşısı Hobbe, Topçu Binbaşısı Restow, Piyade Binbaşısı Kemphoevener idi. Bir yll sonra da Osmanlı ordusunda uzun müddet hizmet edecek olan Albay Colmar von Der Goltz gelmiş ve Köhler'in ölümü üzerine heyet başkanı olmuştur. Alman heyet başkanı Colmar von Der Goltz, adını Türk tarihine "Golç Paşa" olarak yazdırmıștır. ${ }^{44}$

Goltz, Berlin Askerî Üniversitesi'nde harp tarihi öğretmenliği yapmıştır. Aynı zamanda Alman İmparatoru II. Wilhelm'e de harp tarihi dersleri vermiștir. Alman heyeti başkanı olduktan sonra Osmanlı ordusuna ait askerî eğitim kurumlarında reformlar yapmaya başlamıştır. Osmanlı ordusuna uygulamalı eğitim (tatbikat, atış, harp oyunu vb.) vermiștir. Goltz, Harp Akademisi'nde (Erkan-1 Harbiye Mektebi) ilk kez tabiye ve harp tarihi derslerini, 1907 'de nazarî ve tatbiki olarak okutmuştur. ${ }^{45}$ Ancak burada harp tarihi bir ders konusu olarak kurmay subayların yetiştirilmesine yardımcı olmak maksadıyla görülmüştür.

Osmanlı ordusunda gerçek anlamda harp tarihinin, teşkilat halini alması ise I. Dünya Savaşı döneminde (29 Mart 1916'da) İstanbul'da Karargâhı Umumiye'nin (Erkânı Harbiye) 16. Şubesi olarak "Tarihi Harp"in kurulmasıyla başlamıștır. Bu teşkilat askerî tarih olaylarına ait belgeleri toplayarak bir arşiv kurmaya çalışmıștır. 1917'de "Harp Cerideleri ile Vesaik-i Harbiye Dosyaları Hakkında Talimat" (Harp

44 Baron Colmar von der Goltz (Golç Paşa), 1870-1871 Alman-Fransız Savaşı'na katılmıştır. 1883’te Osmanlıya gönderilen Alman heyetinde görev almıştır. Erkan-1 Harbiye Harp Tarihi Dairesinde çalışmış, Erkan-ı Harbiye, II. Başkanlığında, askerî öğretim kurumlarında, Türk ordusunun ıslahında görev almıştır. 1911'de Alman ordusuna katılarak Feldmareşal olmuştur. 1914'de Türk Umumi Karargâhına atanmış; 1. ve 6. Ordu Komutanlıklarında bulunmuştur. 1916'da Bağdat'ta ölmüştür.

Muzaffer Erendil, Askerî Tarih ve Türklerde Askerî Tarih Çalışmaları, Genelkurmay Basımevi, Ankara, 1990, s. 13 vd. 
Cerideleri ile Harp Belgeleri Dosyaları Hakkında Yönetmelik) çıkarılarak askerî tarih çalışmaları yönlendirilmiştir. 16. Şube, 10 Kasım 1919'da 8. Şubeye dönüştürülmüş ve olaylara ait belge tasnifine başlanmıştır. Olayların gruplandırılmasında "Balkan Harbinden Önceki Harpler”, "Balkan Harbi”, “1. Dünya Harbi”, “Sağlık Harp Tarihi”, "Veteriner Harp Tarihi” ve "Arşiv" başlıkları saptanmıştır. Erkânı Harbiye-i Umumiye, Tarihi Harp Şubesi, 3 Temmuz 1920 yllında, "Tarih-i Harp Tahrir Heyeti” (Harp Tarihi Yazma Kurulu) adıyla, askerî tarih çalışmalarını sürdürmüştür. Adı geçen kurul, 1921'de Tarihi Asker'i Encümeni; 1922 yılında “Genelkurmay Encümeni” adını aldıktan sonra aynı yıl "Tarihi Harp Şubesi”, 1926 yılında da "Harp Tarihi Dairesi” olmuştur. $^{46}$

Kısaca anlatılan bu süreçte Bursalı Mehmet Nihat Bey, ilk harp tarihi çalışmalarının içinde olmuş ve bizzat kurucuları arasında yer almıştır. Nihat Bey, 1907'de Harp Akademisi'nde öğrenci olmasından dolayı sınıf arkadaşlarıyla birlikte ilk kez nazarî ve tatbiki harp tarihi alan şanslı öğrencilerden olmuştur. Harp tarihinin önemini bu dönemde kavramıştır.

Bursalı Mehmet Nihat Bey, askerlik hayatı boyunca harp tarihi açısından önemli olan kişisel notlarını harp tarihine vesika oluşturması bilinciyle hazırlamaya başlamıştır. Özellikle Balkan ve I. Dünya Harpleri esnasında gelecek kuşakların ders alabilmesi için tanık olduğu olayları objektif bir biçimde yazmıştır. Osmanlı Erkânı Harbiyesi, Bursalı Mehmet Nihat Bey’in bu özelliğini takdir etmesinden olacaktır ki genç bir subay olmasına rağmen 30 Eylül 1918'de İstanbul'da Yıldız Sarayı'nda bulunan Harp Akademisi Müdür Yardımcılığı'na atamış ve ardından Harp Akademisi ile ilgisi sürmek koşuluyla Erkânı Harbiye, 16. Şubede (Tarihi Harp) görevlendirmiştir. Bu şubenin gerçek anlamda Harp Tarihi şubesi olması için çok çalışmış, bilgi ve tecrübelerini aktarmıştır. 1918'den itibaren Harp tarihi açısından önemli yabancı kaynakları Türkçeye çevirmeye ve tanık olduğu savaşları yazmaya başlamıștır. 10 Kasım 1919'da 16. Şubenin 8. Şubeye dönüştürülmesi ve modern anlamda harp tarihi için arşiv oluşturmak üzere, olaylara ait belge tasnifine başlanmasında etkin rol almıştır. Kurtuluş Savaşı'nda Büyük Taarruz'a da katılan Bursalı Mehmet Nihat Bey, Cumhuriyet döneminde harp tarihi çalışmalarına hız vermiştir. 29 Ağustos 1923 - 06 Şubat 1926 yılları arasında Harp Akademileri Harp Tarihi Öğretmenliği ve Genelkurmay Neşriyat Şube Müdürlüğü yapmıştır. 1928'e kadar İstanbul ve Çanakkale'de harp tarihi konferansları vermiş, bizim tespit edebildiğimiz kadarıyla 39 harp tarihi eserini ülkemize kazandırmıştır. Kendisinden sonra harp tarihçisi olacak öğrenciler yetiștirmiștir. ${ }^{47}$

46 Erendil, Askerî Tarih ve ..., s.15.

47 Emekli Tuğgeneral Nurettin TüRSAN İle Yapılan Mülakat, Konak/İzmir, 05.03.2014. 


\section{5. Şehit Olduğu Hadise}

Kurmay Yarbay Bursalı Mehmet Nihat Bey'in şehadet olayı şu şekilde cereyan etmiştir;

Cumhuriyet Döneminde, Türk ordusunda yeni bir teşkilatlanma anlayışına gidilerek Kara Kuvvetlerine bağlı, üç ordu ve bunlara bağlı kolordular, bağımsız tümenler ve müstahkem mevki komutanlıkları kurulmuştur. Bunlardan biri de İzmir Müstahkem Mevki Komutanlığı'dır. Bu komutanlığa bağlı birlikler piyade ve topçu kıtalarından oluşmuştur. Komutanlığın görevi İzmir şehrini ve körfezini korumaktır.

14 Temmuz 1928'de İzmir Müstahkem Mevki Komutanı Tümgeneral Ali Fuat (Erden) Paşa, beraberindeki askerlerle kendisine bağlı Urla civarındaki birlikleri İzmir Müstahkem Mevzi Mevki Piyade Liva Komutanı Kurmay Yarbay Bursalı Mehmet Nihat Bey ile denetlemek için, İzmir Müstahkem Mevki Komutanlığg'nın karargâhı olan Konak'ta bulunan Sarıkışla'dan ${ }^{48}$ iki araçla yola çıkmıştır. Birinci araçta Müstahkem Mevki Komutanı Tümgeneral Ali Fuat Paşa, Kurmay Başkanı Kurmay Yarbay Çobanoğlu Ömer Zeki Bey, Ali Fuat Paşa'nın emir subayı ve şoför; ikinci arabada ise İzmir Müstahkem Mevzi Mevki Piyade Liva Komutanı Kurmay Yarbay Bursalı Mehmet Nihat Bey, Topçu Binbaşı Abdullah Bey ve şoför İzmirli Rıfat Efendi vardır. Denetlemelerini bitiren ekip dönüş yolculuğu için tekrar araçlarına binmiştir. Urla'ya giderken Tümgeneral Ali Fuat Paşa'ya Kurmay Başkanı Kurmay Yarbay Çobanoğlu Ömer Zeki Bey eşlik etmiştir. Fakat dönüş yolculuğuna Zeki Bey üst rütbeli bir subayla denetleme hakkında konuştuğu için geç kalmış ve Ali Fuat Paşa'nın aracına binememiştir. Bu sebeple Ali Fuat Paşa, emir subayıyla birlikte yola çıkmıştır. Kurmay Yarbay Bursalı Mehmet Nihat Bey ise Kurmay Yarbay Çobanoğlu Ömer Zeki Bey'in konuşmasını bitirmesini beklemiş ve Çobanoğlu Ömer Zeki Bey’i kendi aracına almıştır. Kurmay Yarbay Çobanoğlu Ömer Zeki Bey, şoförün yanına sağ ön tarafa arka sağ koltuğa ise Kurmay Yarbay Bursalı Mehmet Nihat Bey ve sol arka koltuğa Topçu Binbaşı Abdullah Bey oturmuştur. ${ }^{49}$ Üç subay ve şoförün bulunduğu araç Urla'dan geç hareket ettiği için ilk araçla arasında yaklaşık 1 km’lik bir fark olmuştur. Öndeki araç, İzmir'in Güzelbahçe semti sınırları içinde bulunan ve o günkü adıyla Klizman denilen sahil civarına saat 21.00 sıralarında gelmiştir. Araç yola devam ederken keskin bir düdük sesi ve ardından dur ihtarı duyulmuştur. Tümgeneral Ali Fuat Paşa, şoföre durması için hemen emir vermiştir. "Dur" ihtarının yapılmasının nedeni:

İzmir ve çevresinde bir süredir aranmakta olan Kozanlı Kör Mümin adında bir kaçak ve adamlarıdır. Hapishane firarisi olan Kozanlı Kör Mümin’in, Seferihisar

48 Sarıkışla hakkında ayrıntılı bilgi edinmek için bkz. İsmail Hakkı Akansel, İzmir Tarihî Sarıkışla ve Tarihî Orduevi, Harp Akademileri Basımevi, İstanbul, 2010, s. 28 vd.

49 İzmir yerel gazetelerinden Ahenk, 16 Temmuz 1928 Pazartesi günü olay hakkında çıkan haber için bkz. Ekler Bölümü Ek 11-12; Ayrıca araçlardaki oturma planı için bkz. İsmail Hakkı Akansel, Güzelbahçe Şehitleri, İzmir Büyükșehir Belediyesi, İzmir, 1996, s.75. vd., Ekler Bölümü Ek 20. 
ve çevresinde saklandıkları ihbarı gelmiștir. İhbara göre Kör Mümin ve adamları Seferihisar'dan otomobil ile İzmir’e kaçacaktır. İhbar üzerine jandarma harekete geçmiş ve sıkı bir takip içinde Kozanlı Kör Mümin ve adamlarının geçiş güzergâhı olan noktaları aramaya başlamıştır. Arama noktalarından biri de bugün İzmir'den sahil yolu ile Urla yönüne giderken Güzelbahçe'nin merkezine, sola dönmeden önceki trafik ışıllarının $50 \mathrm{~m}$ gerisinde bulunan dere üzerindeki köprü olmuştur. ${ }^{50}$ İzmir jandarma ekipleri kaçakların geçişini engellemek amacıyla bu köprüde pusu kurmuşlardir.

Ali Fuat Paşa'nın aracını da şüphe üzerine durdurmuşlardır. İzmir Jandarma birliğinden Yahya Çavuş, araca yaklaşmış ve Tümgeneral Ali Fuat Paşa'yı görünce kendisini saygıyla selamlayarak araca yol vermiştir.

Kurmay Yarbay Çobanoğlu Ömer Zeki Bey, Kurmay Yarbay Bursalı Mehmet Nihat Bey ve Binbaşı Abdullah Bey'i taşıyan diğer araç ise süratle öndeki araçla arasındaki farkı kapatmaya çalışmıştır. Araç jandarma arama noktasına ulaştığı anda jandarma erinin düdüğü tekrar duyulmuştur. Düdük birkaç kez çalınmasına rağmen araç hızı nedeniyle hemen duramamış ve 50 metre kadar ileri giderek köprüyü geçmiștir. Otomobilin kaçtığını zanneden jandarma eri Tireli Yusuf, pusudan fırlamış, durdurma ve korkutma amacıyla tüfeğini doğrultarak aracın tekerleğine bir el ateş etmiştir. Acı bir tesadüf sonucu jandarma eri Yusuf'un tekerleği hedefleyerek açtığı ateş hedefinden saparak otomobilin sağ arkasında oturan 42 yaşındaki Kurmay Yarbay Bursalı Mehmet Nihat Bey'in ensesinden girmiş, sağ ön koltukta oturmakta olan 26 yaşındaki Kurmay Yarbay Çobanoğlu Ömer Zeki Bey'in ensesine isabet ederek boynunun ön tarafından çıkmışır. İki subayında aldığı yara büyük olduğu için aşırı kan kayberek olay yerinde şehit düşmüşlerdir. ${ }^{51}$

Olaya sebebiyet veren jandarma eri Tireli Yusuf büyük bir üzüntü içinde silahını Yahya Çavuş'a teslim etmiştir. Hadise derhal İzmir'e bildirilmesi sonucu Dönemin İzmir Valisi ve aynı zamanda Harp Akademisinden Bursalı Mehmet Nihat Bey'in sınıf arkadaşı olan Kazım Dirik ve beraberindeki erkân olay yerine gelmiştir. Hadisenin cereyanı ile ilgili tahkikatlar yapılmış ve Tireli Yusuf ölüme sebebiyet vermekten ceza almıştır.

Şehitlerin naaşı Küçükyalı'da bulunan Karantina Semti'ndeki askerî hastaneye getirilmiştir. Kurmay Yarbay Çobanoğlu Ömer Zeki Bey'in İstanbul'daki eşi ile Kurmay Yarbay Bursalı Mehmet Nihat Bey'in İzmir Karşıyaka'daki eşi Ayșe Sıdıka Hanım hadiseden haberdar edilmiştir. Cenazeler 15 Temmuz 1928 günü devlet erkânının

50 Urla ve Seferihisar yönünden İzmir'e gidecek ve İzmir yönünden bu bölgelere gidecek taşıtların o dönem için tek geçiş noktası derenin üzerindeki köprüdür; Emekli Orgeneral İsmail Hakkı AKANSEL İle Yapılan Mülakat, Balçova/İzmir, 04.03.2014.

51 İzmir yerel gazetelerinden Anadolu, 16 Temmuz 1928 Pazartesi günü olay hakkında çıkan haber için bkz. Ekler Bölümü Ek -13-14. 
yanı sıra yaklaşık bin kişinin katılımıyla Bornova'nın Altındağ semtinde yer alan İzmir'in en eski gömü yerlerinden Kokluca Mezarlı̆̆ı'na defnedilmiştir.

Kabirlerinin başında bir konuşma yapan Tümgeneral Fuat (Erden) şu sözleri söylemiştir: ${ }^{52}$

"Dün bu saatlerde bir tepe üzerinde beraber çalışıyorduk. Orada bu klymetli arkadaşlarımızın zekâlarından, kıymetli tecrübelerimden vatan uğruna yararlanıyorduk. Okuldan çıktıkları bugüne kadar hemen hemen her cephede ve her sahada kıymetli hizmetler ifa etmiş olan bu iki arkadaştan biri Piyade Liva (Tugay) Komutanlı̆̆ını, diğeri kurmay başkanlı̆̆ını ifa ediyorlardı. Vazifeden dönerken hatır ve hayale gelmeyen basit bir sebeple, önemsiz bir kaza ile şehit olmalarından dolayı üzüntümüz çok büyüktür."

1Şehit düşen subaylarımızın isimleri İzmir'deki iki caddeye verilmiştir. Şehit Kurmay Yarbay Bursalı Mehmet Nihat Bey'in ismi Mithatpaşa Caddesi üzerindeki İzmir Endüstri Meslek Lisesi binasının arka tarafında bulunan Türkiye Muharip Gaziler Derneği'nin önündeki caddeye verilmiștir. Aynı hadisede şehit düşmüş Kurmay Yarbay Çobanoğlu Ömer Zeki Bey’in ismi ise Konak'ta Saat Kulesi tarafından Kemeraltı Çarşı yönüne gidildiğinde ilk sağdaki binada yer alan İş Bankası'nın arkasındaki bir zamanlar cadde iken önüne bina yapılmasıyla çıkmaz sokak olan caddeye verilmiştir. Bursalı Mehmet Nihat Bey’in şahadetinin ardından 1929 Temmuz'unda İzmir Belediyesi bütçesinden 500 lira ayrılarak mezarı mermerden yaptırılmıştır. ${ }^{53} \mathrm{Bu}$ mezarın bakım ve onarımı, temizliği ise Askerî Ağır Bakım Fabrikası Komutanlığına verilmiştir. Bursalı Mehmet Nihat Bey’in şehit düştüğü yerde ise bir anıt yapıldığı ancak bu anıtın zaman içinde kötü bir hale gelmesinden dolayi ${ }^{54} 15$ Kasım 1973'te İstihkâm Okulu ve Eğitim Merkezi ile Eğitim Merkezi Komutanlığı'nın ortak yürüttüğü çalışma ile yeni bir anıt yapılmıştır. ${ }^{55}$

Bursalı Mehmet Nihat Bey'in eşi Ayşe Sıdıka Hanım, geleneklere göre eşinin kırkının çıkmasını bekledikten sonra Karşıyaka'dan taşınarak Mehmet Nihat Bey’in memleketi Bursa’ya yerleşmiştir. Burada da uzun süre kalmayan Ayşe Sıdıka Hanım,

52 İsmail Hakkı Akansel, İkinci Dünya Savaşı Öncesi ve Sonrası İzmir Gazinosu, Harp Akademileri Basımevi, İstanbul, 2012, s. 54 vd.; Anıtın fotoğrafı için bkz. Ekler Bölümü Ek 16.

53 Bursalı Mehmet Nihat Bey'in Kokluca mezarlığında mezarının yapılması hakkında gazete haberi için bkz. Ekler Bölümü Ek 15.

54 Emekli Orgeneral İsmail Hakkı AKANSEL ...

55 Akansel, Güzelbahçe Şehitleri, s.72. vd.; Engin Berber - Serhan Kemal Saygı, Tarihten Günümüze Güzelbahçe Tarihi, Güzelbahçe Belediyesi Kültür Yayınları, İzmir, 2013, s. 149.; Şehitlerin anıtı için bkz. Ekler Bölümü Ek 18.; Anıt yanındaki esnaflar ve semt sakinlerinden görüștügümüz insanların Nihat Bey hakkında herhangi bir bilgi sahibi olmadıkları ya da olanların ise efsanevi bir şekilde gerçekle ilgisi olmayan hikayeler anlattıkları tespit edilmiştir. Ayrıca 2014'te girişimlerimiz sonucu Güzelbahçe Belediyesi anıtı restore etmiştir. 
oğlu Orhan ile İstanbul'un Fatih İlçesindeki Samatya'ya göç etmiştir. Ayşe Sıdıka Hanım, eşi Bursalı Mehmet Nihat Bey'in ölümünden sonra kendisinden kalan notları, kitap çalışmalarını ve evraklarını evine çağırdığı askerî erkâna (eşinin kılıcı, askerî hüviyet belgesi ${ }^{56}$ ve kaşesi haricinde) vermiştir. Bursalı Mehmet Nihat Bey’in, yazmış olduğu bazı eserler ve çalışma notları da dâhil olmak üzere şahsi eşyalarının bugün nerede olduğu bilinmemektedir. Torunu Munis Kirizman'a dedesinden kalan birkaç fotoğraf, kılıç, hüviyet cüzdanı ve pirinç mührü dışında Bursalı Mehmet Nihat Bey'e ait herhangi bir eşyası günümüze ulaşamamıştır. ${ }^{57}$ Ayşe Sıdıka Hanım, 1934'te Soyadı Kanunu çıkınca eşinin şehit düştüğü köyün adını, soyadı olarak almıştır. ${ }^{58}$

\section{Eserleri}

Bursalı Mehmet Nihat Bey'in en büyük eseri 1213 sayfa ve 107 krokiden oluşan üç ciltlik "Balkan Harbi, Trakya Seferi"dir. Eserin 1. ve 2. ciltleri 1924'te 3. cildi de şahadetinden kısa bir zaman önce 1928'de basılmıştır. Balkan Savaşı'na ait bu eserden daha kapsamlı bir eser günümüze kadar yazılmamıştır. Bulgaristan Genelkurmayı da kendi harp tarihini yazarken bu eserden yararlandığını açıklamıştır. 42 yıllık ömrüne 39 eser sığdırması onun geceli gündüzlü yazdığının, aynı zamanda Fransızca, Almanca ve İngilizce harp tarihi eserlerinden binlerce sayfalık çeviriler yaptığının bir göstergesi olmuştur. Türkiye'de Bursalı Mehmet Nihat Bey’in şehit düştüğü 1928'den günümüze 87 yll gibi uzun bir süre geçmesine rağmen onun kadar çok eser veren başka bir harp tarihçisi ${ }^{59}$ görülmemiştir;

\section{a-) Telif Eserleri:}

1. Balkan Harbi, 1328-1329 Trakya Seferi, c. 1, Askerî Matbaa, İstanbul, 1924.

2. Balkan Harbi, 1328-1329 Trakya Seferi (Kırk Kilise Muharebesi), c. 2, Askerî Matbaa, İstanbul, 1924.

56 Askerî hüviyet belgesi için bkz. Ekler Bölümü Ek 21.

57 Kılıcın fotoğrafı için bkz. Ekler Bölümü Ek 17.; Ayrıca Kurmay Yarbay Bursalı Mehmet Nihat Bey’in, şehit düşmeden önce kaleme aldığı çalışma notları ve eserlerde teslim edilmiștir. Ölümünden sonra 2 eseri daha yayımlanmıştır ("1914'ten 1916'ya Kadar Balkan ve Türkiye'de Büyük Harp”, Mecmua-i Askeriye, Sayı: 95, İstanbul, 1934.; Albay Von Montey, Alman-Avusturya Şark Cephesi’nde 1914 Yaz Seferi (Grafik Halinde), Askerî Matbaa, İstanbul, 1930).; Ayşe Sıdıka Hanım, eşinin eşyaları hangi birliğe verdiğini oğlu Orhan'a dahi söylemediğini, torunu Munis Kirizman ifade etmiştir. Bu makale hazırlanırken müracaat ettiğimiz askerî kaynaklardan Kurmay Yarbay Bursalı Mehmet Nihat Bey'e ait olan ve eşi Ayşe Sıdıka Hanım tarafından askerî erkâna verildiği söylenen eşyalar hakkında bir bilgiye ulaşılamamıştır. Ancak araştırmacılar bir gün söz konusu eşyalara ulaşabilirlerse belki de Kurmay Yarbay Bursalı Mehmet Nihat Bey’in bilmediğimiz başka eserleri de gün yüzüne çıabilir.

58 Maalesef nüfus memuru Klizman yazacağı yerde Kirizman yazarak soyadını yanlış yazmıştır. Kurmay Yarbay Bursalı Mehmet Nihat Bey'in oğlu Orhan ve torunu Munis Kirizman soyadlarının düzeltilmesi için defalarca mahkemeye başvurmalarına rağmen olumlu bir netice alamadıkları öğrenilmiştir. Bursalı Mehmet Nihat Bey'in Torunu Munis KİIZZMAN ...

"86 Nolu Askerî Mecmua”, Genelkurmay Başkanlı̆̆ı ATASE Arşivi. 
3. Balkan Harbi-1328-1329 Trakya Seferi (Lüleburgaz Meydan Muharebesi), c. 3, Askerî Matbaa, İstanbul, 1928.

4. Balkan Harbi’nde Çatalca Muharebesi, Konferansı, Askerî Matbaa, İstanbul, $1925 .^{60}$

5. Büyük Harpte Çanakkale Seferi, İlhami Fevzi Matbaası, İstanbul, $1926 .{ }^{61}$

6. Harbi Umumide Seddülbahir Cenup Grupları Muharebatı, İstanbul, 1920.

7. Kadro Tatbikat ve Seyahatlerinin Tertib ve Iddaresi Hakkında Ameli Muhtıra, Askerî Matbaa, İstanbul, 1925.

8. Trakya'da Osmanl-Bulgar Muharebesi, İstanbul, 1919.

9. Meşhur Osmanlı Sefer ve Muharebeleri'nde Sevk ve İdare, İstanbul, Basıldığı tarih tespit edilememiştir.

10. 13 üncü Kolordu’nun İran Seferi, Askerî Matbaa, İstanbul, 1920.

11. İstiklal Seferleri, Askerî Matbaa, İstanbul, Basıldığı tarih tespit edilememiştir.

12. Zabitin Harp Çantası (Kurmay Subay Muhtırası), İstanbul, Basıldığı tarih tespit edilememiştir.

13. Kıtaat-ı Cesime'nin Tabiyece İstihdamları Hakkında Muvakkat Talimname, İstanbul, Basıldığı tarih tespit edilememiştir.

14. Atlı Farazi Tatbikat ve Tatbikat Seyahatlerinin Suret-i Tertip ve İdaresi, İstanbul, Basıldığı tarih tespit edilememiştir.

15. “1870-71 Seferi”, Erkan-ı Harbiye Mektebi Külliyatı, c. 2, Sayı: 18, İstanbul, 1925. ${ }^{62}$

60 Söz konusu eser Balkan Harbinde Trakya Seferi eserlerinin 4. cildi durumundadır. Kurmay Yarbay Bursalı Mehmet Nihat Bey, katıldığı Balkan Savaşlarındaki anılarına ve resmi yazışmalara dayanarak hazırladığı bir konferansı içeren kitapta Lüleburgaz Muhaberebesi'nden sonra Çatalca Muhaberesi'ne kadar geçen süredeki olaylar ve Çatalca Muharebesi'nin safhalarını anlatmaktadır. Eser 70 sayfa, fihrist, metin harici 2 kroki ve kaynakçadan oluşmaktadır.; Askerî Tarih Yayınları Bibliyografyası, Genelkurmay Basımevi, Ankara, 1987, s. 49 vd.; Çatalca Kaymakamlığı katkılarıyla 2012 yllında Kurmay Yarbay Bursalı Mehmet Nihat Bey'in aziz hatırasını yaşatmak ve Balkan Harbi'nin 100. Yılı münasebetiyle Kasım Bolat tarafından Türkçeye çevrilmiştir. Eserin ilk ve yeni baskıları için bkz. Ekler Bölümü Ek 10.

61 Bursalı Mehmet Nihat Bey'in kurucusu olduğu Türk Şehitlikleri İmar Vakfı, 2012 yılında Elif Berfi'nin çevirisi ve akademisyen Murat Karataş'in yayına hazırlamasıyla eser yeniden yayınlamıştır.

62 Bursalı Mehmet Nihat Bey'in bu makalesi toplamda 217 sayfa, fihrist, giriş ve 6 krokiden oluşmuştur. Kendisinin Harp Akademisi'nde okutulan ders notlarından özel olarak hazırlanmıștır. Kitabın konusu 1870-1871 Fransız-Alman Seferi'dir. Bu harbin siyasi nedenleri Fransız ve Alman ordularının kuvvet durumları, her iki ordunun stratejileri ve Sedan Seferi ayrıntılı olarak incelenmiştir. Yazar olayları kronolojik esaslara göre anlatmaktansa, kendi şahsi görüşlerini de katıp, bir münakaşa, tetkik ve fikir yürütme ortamı yaratmak istediğini söylemektedir. Gerçekten savaş ve barış, siyaset ve askerlik konuları, karşılıklı etkileşimleri dikkate alınarak incelenmiştir. Eser yayınlandığı sırada Mehmet Nihat Bey, Harp Akademisi’nde yarbay rütbesiyle Askeri Tarih Öğretmenidir.; Askerî Tarih Yayınları ..., s. 49 vd. 
16. "Irak Cephesi Muharebatından”, Мecmua-i Askeriye, Sayı: 15-16, İstanbul, 1 Haziran- 1 Temmuz $1920 .^{63}$

17. “1914'ten 1916'ya Kadar Balkan ve Türkiye'de Büyük Harp”, Mecmua-i Askeriye, Sayı: 95, İstanbul, 1934. ${ }^{64}$

\section{b-) Çeşitli Dillerden Çevirdiği Harp Tarihi Eserleri:}

18. Büyük Harp, c. 1, (Almancadan çeviri), İstanbul, 1926.

19. Büyük Harp, c. 2, (Almancadan çeviri), İstanbul, 1926.

20. Büyük Harp, c. 3, (Almancadan çeviri), İstanbul, 1926.

21. Büyük Harp, c. 4, (Almancadan çeviri), İstanbul, 1926.

22. Larşer, Binbaşı M., Büyük Harp’te Türk Harbi: Harbin Anasır ve Mukaddemadı ve Heyet-i Umumiyesinin Hülası, (Fransızcadan çeviri), c. 1, Askerî Matbaa, İstanbul, 1927.

23. Larşer, Binbaşı M., Büyük Harp’te Türk Harbi: Türk Cephelerindeki Harekât ve Muhaberat, (Fransızcadan çeviri), c. 2, Askerî Matbaa, İstanbul, 1928.

24. Larşer, Binbaşı M., Büyük Harpte Türk Harbi: Tali Darülharekâtlar ve Harbin Neticesi, (Fransızcadan çeviri), c. 3, Askerî Matbaa, İstanbul, 1928.

25. Stegeman, Herman, Harbi Umumi Tarihi, c. 1, (Almancadan çeviri), Askerî Matbaa, İstanbul, 1918.

26. Stegeman, Herman, Harbi Umumi Tarihi, c. 2, (Almancadan çeviri), Askerî Matbaa, İstanbul, 1918.

27. Kol, General, Harbi Umumi'nin İzar ve İdaresinde Alman Erkan-ı Harbiyesi, (Almancadan çeviri), Askerî Matbaa, İstanbul, Basıldığg tarih tespit edilememiştir.

28. Laterzac, Harbi Umumide Fransız Sefer Planı ve Harbin Ilk Ayı, (Fransızcadan çeviri), Askerî Matbaa, İstanbul, Basıldığı tarih tespit edilememiştir.

29. Harbi Umumide General Moltke'nin Mektupları ve Hatıratı, (Almancadan çeviri), Askerî Matbaa, İstanbul, 1924.

30. Roux-Charleroux, F., Çanakkale Seferi, (Çevirenler: Bnb. Nihat ve Yzb. Asım), Askerî Matbaa, İstanbul, 1921.

31. Napoleon Muharebatı, (Fransızcadan çeviri), Askerî Matbaa, İstanbul, Basıldığı tarih tespit edilememiştir.

63 Eser Mehmet Nihat Bey'in konferans notlarından oluşturulan bir makaledir. Toplamda 998 sayfa; giriş, 9 kroki ve 1 çizelgeden ibarettir. Mehmet Nihat Bey'in 6. Tümenin Erkan-1 Harbi olarak katıldığı, I. Dünya Harbindeki İran Seferini anlatmaktadır. Eser yayınlandığı sırada Mehmet Nihat Bey, Harp Akademisi'nde binbaşı rütbesiyle Askeri Tarih Öğretmenidir.; Askerî Tarih Yayınları ..., s. 49 vd.

Kurmay Yarbay Bursalı Mehmet Nihat Bey'in ölümünden sonra yayımlanmıştır. 
32. Linge ve Namur'un Zaptı, (Almancadan çeviri), Askerî Matbaa, İstanbul, Basıldığg tarih tespit edilememiştir.

33. Falkenhein, Eric von, 1914-1916 Senelerinde Alman Başkumandanliğı (General Falkenhayn)'in Hatıratı, (Almancadan çeviri), Askerî Matbaa, İstanbul, 1924.

34. Rus-Japon Harbi, Askerî Matbaa, İstanbul, Basıldığı tarih tespit edilememiştir.

35. Nıcolaı Walter, Büyük Harpte İstihbarat Hizmeti Matbuat ve Efkârı Umumiye, Askerî Matbaa, İstanbul, 1925.

36. Nicola1, Walter, Gizli Kuvvetler, Askerî Matbaa, İstanbul, 1925.

37. Joachım, Ritter, Harbi Umum Tenkidatı, Askerî Matbaa, İstanbul, 1923.

38. Harbi Umumi Silsiler Neşriyatı Liyej ve Namur Kalelerinin Suret-i Zabtı, Askerî Matbaa, İstanbul, Basıldığı tarih tespit edilememiştir.

39. Montey, Albay Von, Alman-Avusturya Şark Cephesi'nde 1914 Yaz Seferi, (Grafik Halinde), Askerî Matbaa, İstanbul, 1930. ${ }^{65}$

\section{Sonuç}

1886'da Bursa'da doğan Mehmet Nihat Bey, 14 Ocak 1903’te Kara Harp Okulu'na girmiş ve 27 Mayıs 1905 'te teğmen rütbesiyle mezun olmuştur. Aynı yıl dereceye girmesinden dolayı Harp Akademisi’nde öğrenim görmeye hak kazanmıştır. Kendisiyle birlikte Harp Akademisi'nde öğrenim gören sınıfın adı 64. Dönemdir. Bu dönem harp tarihini ilk kez nazarî ve tatbiki olarak görmüştür.

Bursalı Mehmet Nihat Bey, 1905'te Harp Akademisi'ne başlamasına rağmen ancak 1912'de mezun olacaktır. Çünkü dönemindeki siyasi çalkantılar ve savaşlar nedeniyle 64. Dönem öğrencileri sürekli cephelere gönderilmiştir. Harp Akademisi'ndeki öğrenim hayatı içinde görevlendirildiği yerler şunlardır:

1907'de staj eğitimi için 78. Alay, 2. Tabur, 5. Bölüğe gönderilmiş ardından da birliğiyle birlikte Adana ve havalisinde çıkan isyanları bastırmak için İskenderun ve Bilan'a gitmiştir. 20 Kasım 1910'da 2. Ordu, 78. Alay, 2. Tabur, 1. Bölüğe tayin olmuştur. Bu görev esnasında eşi Ayşe Sıdıka Hanım ile evlenmiştir. İstanbul'a tekrar Harp Akademisi'ndeki eğitimine devam etmesi için çağrılmıştır. 1912'de oğlu Orhan doğmuştur. Aynı yıl Harp Akademisi 3. Sınıfındayken Trablusgarp Harbi’ne katılmıștır. Dönüşünde ise 26 Eylül 1912'de Balkan Harplerine katılacaktır. Savaş esnasında harp tarihi notlarını yazmaya başlamıştır. Türk ordusundaki eksik ve hataları tarafsız bir gözle objektif olarak kaleme almıştır.

65 Kurmay Yarbay Bursalı Mehmet Nihat Bey'in ölümünden sonra yayımlanmıştır. 
22 Ekim 1913'te Kara Harp Okulu'na Harp Tarihi ve Coğrafya öğretmenliği vekilliğine tayin edilmiştir. I. Dünya Harbi başlayınca Çanakkale, Kafkas Cephelerine, İran ve Hanekin harekâtlarına katılmış ve bu harpler esnasında harp tarihi notlarını tutmaya devam etmiştir. 30 Eylül 1918'de Harp Akademileri Müdür Yardımcısı olmuş ve bu görevi esnasında, harp tarihi bilgisinden dolayı Erkânı Harbiye'nin yeni oluşturduğu 16. Şubeye (Tarihi Harp) atanmıștır. Bursalı Mehmet Nihat Bey, bu şubenin gerçek anlamda Harp Tarihi şubesi olması için çok çalışmış, bilgi ve tecrübelerini aktarmıştır. 1918'den itibaren Harp tarihi açısından önemli yabancı kaynakları Türkçeye çevirmeye ve tanık olduğu savaşları yazmaya başlamıştır. 10 Kasım 1919'da 16. Şubenin 8. Şubeye dönüştürülmesi ve modern anlamda harp tarihi için arşiv oluşturmak üzere, olaylara ait belge tasnifine başlanmasında etkin rol almıştır.

Kurtuluş Savaşı döneminde Mustafa Kemal Paşa'nın emriyle Anadolu'da savaşacak subayları Harp Akademisi'nde yetiştirmeye devam etmiștir. Yine Mustafa Kemal Paşa'nın emriyle 3 Mayıs 1922'de Anadolu'ya geçerek Büyük Taarruz'a katılmıştır. İstiklal madalyası alan Bursalı Mehmet Nihat Bey, Cumhuriyet döneminde Harp Akademisi'nde harp tarihi öğretmenliğine devam etmiştir. 14 Temmuz 1928'de son görev yeri olan İzmir'de bir görev dönüşü kaza kurşunu ile şehit düşmüştür.

Cumhuriyetin ilk harp tarihçisi olan Bursalı Mehmet Nihat Bey, tespit ettiğimiz kadarıyla 39 eser kaleme almıştır. Eserlerinde katıldığı savaşlarda Türk ve düşman birliklerinin yapmış oldukları taktiksel ve stratejik hatalar ayrıntılı bir şekilde inceleyip; eserlerini eleștirel, açık ve özgün bir üslupla kaleme almıştır. Bursalı Mehmet Nihat Bey, yaşadığı dönem ve katıldığı savaşlar itibarıyla döneminin koşullarını objektif bir süzgeçle analiz etmesini bilmiş ve kendinden sonra gelecek nesillere büyük eserler bırakarak faydalı olmuştur. Bunun yanında, döneminde tanık olduğu olayları not etmesi itibari ile Yakın Çağ tarihine adını altın harflerle yazdırmıș ve tarihimizin canlı tanığı olmuştur.

Balkan ve I. Dünya Harpleri hakkında bilgi sahibi olmak isteyen araştırmacıların ilgi odağı hâline gelen Bursalı Mehmet Nihat Bey'in neşrettiği eserler harp tarihi açısından büyük önem arz etmektedir. Bursalı Mehmet Nihat Bey, Cumhuriyet tarihinin ilk harp tarihçisi olmasının yanında İstanbul ve Çanakkale'de I. Dünya Harbi (Çanakkale Harbi) ve Balkan Harpleri hakkında ilk harp tarihi konferanslarını vermiştir. 


\section{KAYNAKLAR}

\section{Arşivler:}

APİKAM Arşivi.

Genelkurmay Başkanlığı ATASE Arşivi.

Kara Kuvvetleri Arşivi.

Millî Savunma Bakanlığı Arşivi.

\section{Eserler}

Akansel, İsmail Hakkı, Güzelbahçe Şehitleri, İzmir Büyükşehir Belediyesi İzmir Yayıncılık ve Tanıtım Hizmetleri Ticaret ve Sanayi Aş., İzmir 1996.

Akansel, İsmail Hakkı, İkinci Dünya Savaşı Öncesi ve Sonrası İzmir Garnizonu, Harp Akademileri Basımevi, İstanbul 2012.

Akansel, İsmail Hakkı, İzmir Tarihi Sarıkışla ve Tarihi Orduevi, Harp Akademileri Basımevi, İstanbul 2010.

Askerî Tarih Yayınları Bibliyografyası, Genelkurmay Basımevi, Ankara 1987.

Atabay, Mithat, Mustafa Kemal'in Himayelerinde Şehitlikleri İmar Cemiyeti Nasıl Kuruldu? Nasıl Gelişti?, Türk Şehitlikleri İmar Vakfı Yayınları, İstanbul 2012.

Berber, Engin - Saygı, Serhan Kemal, Tarih Öncesinden Günümüze Güzelbahçe Tarihi, Güzelbahçe Belediyesi Kültür Yayınları, İzmir 2013.

Bursalı Mehmet Nihat, Balkan Harbi, 1328-1329 Trakya Seferi, C.1, Askerî Matbaa, İstanbul, 1924.

Bursalı Mehmet Nihat, Balkan Harbi’nde Çatalca Muharebesi Konferansı, Askerî Matbaa, İstanbul 1925.

Bursalı Mehmet Nihat, Balkan Harbinde Çatalca Muharebesi, (Transkript eden: Kasım Bolat), Çatalca Kaymakamlığı Yayınları, İstanbul 2013.

Bursalı Mehmet Nihat, Balkan Harbi-1328-1329 Trakya Seferi (Kırk Kilise Muharebesi), c. 2, Askerî Matbaa, İstanbul 1924.

Bursalı Mehmet Nihat, Balkan Harbi-1328-1329 Trakya Seferi (Lüleburgaz Meydan Muharebesi), c. 3, Askerî Matbaa, İstanbul 1928.

Bursalı Mehmet Nihat, Büyük Harp, c. 1, (Almancadan çeviri), İstanbul 1926.

Bursalı Mehmet Nihat, Büyük Harp, c. 2, (Almancadan çeviri), İstanbul 1926.

Bursalı Mehmet Nihat, Büyük Harp, c. 3, (Almancadan çeviri), İstanbul 1926.

Bursalı Mehmet Nihat, Büyük Harp, c. 4, (Almancadan çeviri), İstanbul 1926.

Bursalı Mehmet Nihat, Büyük Harpte Çanakkale Seferi, (The Gallipoli Campaign in the Great War), (Çeviren: Elif Berfin), Türk Şehitlikleri İmar Vakfı Kültür Yayınları, İstanbul 2012. 
Bursalı Mehmet Nihat, Büyük Harpte Çanakkale Seferi, İlhami Fevzi Matbaası, İstanbul 1926.

Bursalı Mehmet Nihat, Zabitin Harp Çantası (Kurmay Subay Muhtırası), İstanbul.

Erendil, Muzaffer, Askerî Tarih ve Türklerde Askerî Tarih Çalışmaları, Genelkurmay Basımevi, Ankara 1990.

Larşer, Binbaşı M., Büyük Harp’te Türk Harbi: Türk Cephelerindeki Harekât ve Muhaberat, (Çeviren: Mehmet Nihat), c. 2, Askerî Matbaa, İstanbul 1928.

Larşer, Binbaşı M., Büyük Harpte Türk Harbi: Tali Darülharekâtlar ve Harbin Neticesi, (çev. Bursalı Mehmet Nihat), c. 1, Askerî Matbaa, İstanbul 1928.

Larşer, Binbaşı M., Büyük Harpte Türk Harbi: Tali Darülharekâtlar ve Harbin Neticesi, (Çeviren: Bursalı Mehmet Nihat), c.3, Askerî Matbaa, İstanbul 1928.

Özakman, Turgut, Diriliş Çanakkale 1915, Bilgi Yayınevi, İstanbul 2011.

Stegeman, Herman, Harbi Umumi Tarihi, (çev. Bursalı Mehmet Nihat), c. 1, Askerî Matbaa, İstanbul, 1918.

Stegeman, Herman, Harbi Umumi Tarihi, (çev. Bursalı Mehmet Nihat), c. 2, Askerî Matbaa, İstanbul, 1918.

Türsan, Nurettin, Büyük Askeri Tarih Öğretmeni Bursalı Kurmay Yarbay Mehmet Nihat Bey, Harp Akademisi Yayınları, İstanbul 1996.

Yıldız, Cemalettin, Bir Komutanın Gözünden Çanakkale Savaşları, Emre Basımevi, Çanakkale 2007.

\section{Dergiler}

Bursalı Mehmet Nihat Bey, "Hatıralara Hürmet”, 86 Nolu Askerî Mecmua, Askerî Matbaa, İstanbul.

Aldoğan, M. Şahin, "Bursalı Mehmet Nihat Bey, Unutulan Türk Büyüğü", NTV Tarih Dergisi, Sayı 15, İstanbul Nisan-2010.

Yılmaz, Aliye, “Amanullah Han'ın Islahatları ve Atatürk ”, SDÜ Fen Edebiyat Fakültesi Sosyal Bilimler Dergisi, Sayı:21, Isparta Mayıs 2010.

\section{Gazeteler}

Vakit, 18 Eylül 1927.

Ahenk, 16 Temmuz 1928.

Anadolu, 16 Temmuz 1928.

Anadolu, 17 Temmuz 1929.

\section{Görüşmeler}

Altındă̆ Kokluca Mezarlı̆̆ı’nda Çalışan Personel İle Yapılan Mülakat, Altındağ-Bornova/İzmir, 24.10.2013. 
Çobanoğlu Zeki Bey Caddesi’ndeki Bölge Esnafi İle Yapılan Mülakat, Konak/İzmir, 15.01.2014. Emekli Orgeneral İsmail Hakkı AKANSEL İle Yapılan Mülakat, Balçova/İzmir, 12.01.2014. Emekli Tuğgeneral Nurettin TüRSAN İle Yapılan Mülakat, Konak/İzmir, 05.03.2014.

Güzelbahçe Belediyesi Kültür İşleri ve Fen İşleri Müdürleri İle Yapılan Mülakat, Güzelbahçe/ İzmir, 01.15.2014.

Güzelbahçe Şehitler Anıtı Etrafındaki Bölge Esnafı İle Yapılan Mülakat, Güzelbahçe/İzmir, 15.01.2014.

Nihat Bey’in Torunu Munis KİRİZMAN İle Yapılan Mülakat, Urla/İzmir, 04.12.2013.

Şehit Nihat Bey Caddesi’nde Bölge Esnafi İle Yapılan Mülakat, Konak/İzmir, 15.01.2014.

\section{İnternet Siteleri}

http://bursazamandergisi.com/yazarlar/bursanin-kinali-kuzulari-2057.html, KAPTANOĞLU, Raif, 16.01.2014.

http://www.ttk.gov.tr/193.255.138.2/takvim.asp?takvim =3\&gun=3\&ay =5\&y $\mathrm{il}=1331 / 21.12 .2014$.

www.geliboluyuanlamak.com/ 12.12.2013.

www.yok.gov. tr/ 12.12.2013.

htt://www.mkutup.gov.tr/ 21.12.2013.

www.tsiv.org.tr/ 28.02.2014. 


\section{Ekler}



Ek 1. Bursalı Mehmet Nihat Bey, eși Sıdıka Hanım (KİRIZMAN) ve oğlu Orhan (KİRİZMAN) ile İstanbul 1914 




Ek 2. Bursalı Mehmet Nihat Bey'in eseri



Ek 3. Bursalı Mehmet Nihat Bey'in yazmıș olduğu

Balkan Harbi-Trakya Seferi-Kırk Kilise(Kırklareli)Muharebesi c. 2 eseri 




Ek 4. Bursalı Mehmet Nihat Bey'in yazmış olduğu Balkan Harbi-Trakya Seferi-Lüleburgaz Meydan Muharebesi) Muharebesi c.3 eseri








Ek 6. Bursalı Mehmet Nihat Bey'in I. Dünya

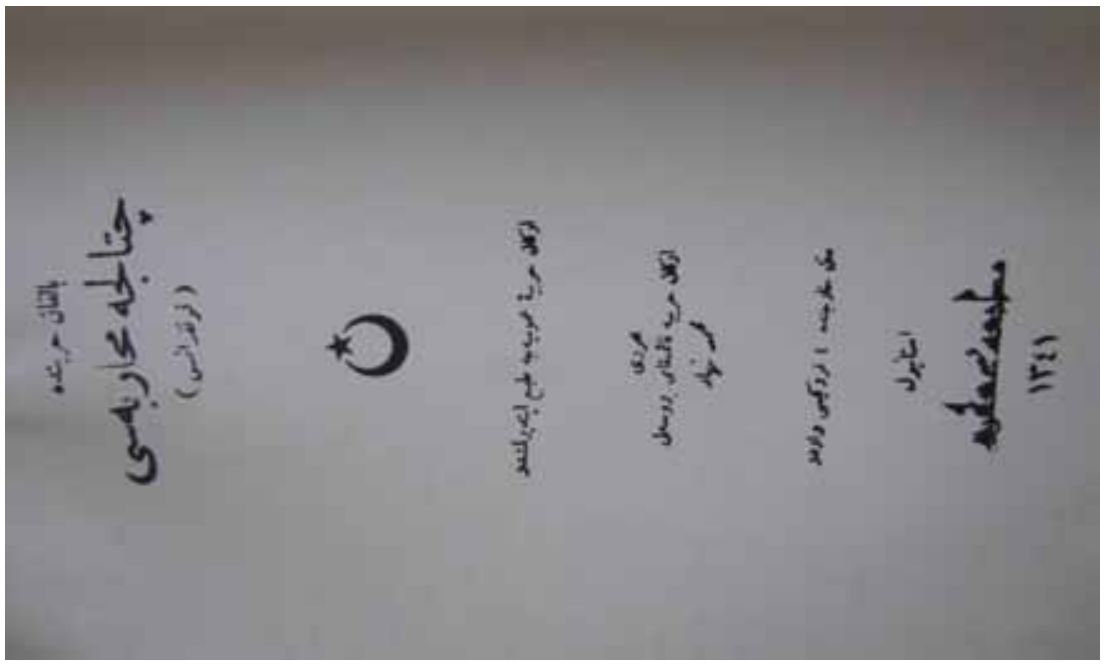

Ek 7. Bursalı Mehmet Nihat Bey'in, "Balkan Harbi’nde Çatalca Muharebesi” ile ilgili verdiği konferanslar 1925 yilında eser olarak basılmıștır. 




Ek 8. Bursalı Mehmet Nihat Bey'in yazmış olduğu Zabitin Harp Çantası adlı eseri 1925



Ek 9. Bursalı Mehmet Nihat Bey (ay yıldızlı), Mustafa Kemal Atatürk ile birlikte 




Ek 10. Bursalı Mehmet Nihat Bey'in Balkan Harbi-Trakya Seferi eserinin 1. cildinde basılmış fotoğrafı, İstanbul 1924



Ek 11. İzmir yerel gazetelerinden Ahenk'te Bursalı Mehmet 


\section{AHENK}

16 Temmuz 1928

Pazartesi

Müessif hadise (üzücü olay) tahkikatı dün yapıldı. Jandarma Yusuf tevkif edilmiştir.

Kıymetli Erkan-1 Askeriyemizden (Kurmay Yarbay) Nihat ve (Kurmay Yarbay) Çobanoğlu Zeki Beylerin hazin ve acıklı ifâ-yi intac eden hadiseyi müessife (olayı gerçekleștiren) hakkında tahkikatta bulunmak üzere dün bir heyet i'zam edilmiștir. Tahkik heyeti vaka mahalinde uzun uzadıya tahkikat yapmış, kurşunu atan jandarmanın bulunduğu mevki ile hadiseye müteakip otomobilin tevkif eylediği mesafeyi ölçmüş ve lazım gelen tetkikat-1 saireyi bil-i'fa raporunu tanzim ve makama takdim etmiştir.

İstihbaratlarımız, nazaran, jandarma neferi tevkif edilmiștir. Buna nazaran, meselenin safahat-i mahkemeden geçecek ve bu suretle neferin kabahati olup olmadığ anlaşılacaktır. Ancak bu meselenin divan-1 harb'de mi yoksa mahkeme-i adliyede mi muhakeme edeceği henüz taayyün etmemiştir.

Mücerred kavanine göre, jandarma neferi me'murin-i mülkiyeden ma'dud olduğu için bu babda evvela jandarmaca tahkikat fezlekesi tanzim ve bu fezlekenin alelusul vilayet idare heyetine verilmesi iktiza etmektedir.

Hadiseyi müteakip gerek jandarma neferi gerek şoför isticvap edilmiştir. Şoför verdiği ifadede jandarma neferinin düdüğünü işittiğini ve hatta düdüğü neferin ağzında iken fark eylediğini söylemektedir.

Ek 12. Ahenk gazetesindeki haberin günümüz alfabesine çevrilmiş hali 16 Temmuz 1928. 




Ek 13. İzmir yerel gazetelerinden

\section{ANADOLU}

16 Temmuz 1928

Pazartesi

Feci bir kaza ordumuza iki kıymetli uzvunu kaybettirdi. Erkan-1 Harb Kaymakamlarımızdan (Kurmay Yarbay) Çobanoğlu Zeki ve (Kurmay Yarbay) Nihat Beyler, hepimizi ağlatan bir kaza kurşununa kurban olarak terki hayat ettiler. Evvel ki gece bütün İzmir halkını şiddetle müteessir eden bir hadise vuku bulmuş ve neticede en kıymetli ümerayı askeriyemizden ikisi şehit düşmüştür.

Samizde mundal cidalata resmi bil'ayan'dan da anlaşılacağı vehiçle hadise feci bir kazadan başka bir şey değildir. Fakat bu kaza Türk ordusuna cidden pahalıya mâl olmuş Erkan-ı Harbiye Kaymakamlarından Çobanoğlu Zeki Bey ve Liva Kumandanı Erkan-ı Harbiye Kaymakamlarımızdan Nihat Bey gibi iki güzide çok yüksek şahsiyet aramızdan ebediyen ayrılmıştır. Aldığımız tafsilata göre hadise şu suretle vakıa olmuştur:

Evvelki gece müstahkem mevki kumandanı Fuat Paşa (Tümgeneral Ali Fuat) hazretleri ile Kaymakam Çobanoğlu Zeki Bey bir otomobil ile Müstahkem Mevki Müdafaası dâhilinde bir teftişe çıkmışlardır. Arkalarından gelen ikinci bir otomobilde de Liva Kumandanlarından Nihat Bey ile Binbaşı Abdullah Bey bulunuyordu. İcap eden teftişatın itimamından sonra Fuat Paşa Hazretleri otomobillerine binerek yola çıkmışlar, Zeki ve Nihat Beyler yüksek rütbeli bir zabıtla görüştükleri için biraz teehhür'le hareket etmişlerdir. Bu suretle iki otomobil arasında bir kilometreden faz- 
la bir mesafe hâsıl olmuştur. Fuat Paşa Hazretlerinin rakip oldukları otomobil tam Kilizman’a gelirken birdenbire keskin bir düdük sesi işitilmiş, otomobil derhal tevkif edilmiştir.

Son zamanlarda Urla ve havalisinde çalı kakıcılık Mümin ve himayelerinin yeni bir melaatına meydan vermemek ve bu haydutları yakalamak üzere Jandarma bütün civarda fevkalade tedabir ittihas etmiş bulunuyordu. Müteaddit mahallelerde Jandarma pusuları vücuda getirilmişti. İște düdük sesi ve tevkif emri bu Jandarma pususundan geliyordu.

Kumandan Paşa'nın otomobilleri durunca, pusudan firlayan bir Jandarma neferi, onlara yaklaşmış Paşa hazretlerini görünce selamlayarak devam etmelerini bildirmiştir. Merhum Zeki ve Nihat Beylerle Abdullah Bey'in bulunduğu otomobil bu esnada henüz yola yeni çıkmış ve Kumandan Paşa hazretlerine yetişebilmek üzere süratle yol almaya başlamıştır. Otomobil pusu mahalline geldiği zaman altmış kilometre süratle yol alıyordu. Bu itibarla jandarma pususundan işitilen düdük sesi ve tevkif emri üzerine araba birdenbire tevkif edilememiş 50 metre kadar ileri gitmiştir ki otomobilin durmayacağı zehabına düșen bir jandarma neferi pususundan fırlamış ve silahını üzerine boşaltmıştır. Ne hain bir tesadüftür ki kurşun, otomobilin arkasında oturmakta olan Kaymakam Nihat Beyin ensesinden girmiş ve ön tarafından çıkarak (Kurmay Yarbay) Çobanoğlu Zeki Beyi de aynı feci ensesinden yaralamış ve ön tarafından çıkmıștır. Gayri kabulü tedavi bir şekilde yaralanan bu iki kıymetli kumandan an ve uhdede vefat etmişler ve otomobilde o sırada tevkif eylemiştir. İki kıymetli Erkan-1 Harp Kaymakamı bu sırada vefat etmiş ve hayata ebediyen gözlerini kapamışlardır.

Jandarma Neferi Tireli Yusuf sebebiyet verdiği bu faciayı görünce ne yapacağını şaşırmış ve derhal mavzerini teslim etmiştir. Hadise telefonla İzmir'e bildirilmiş ve İzmir'den Vali Kazım (DİRIK) Paşa sihhiye ve muavenet-i içtimaiye müdürü Lütfü Bey, polis müdürü Ömer Bey vaka mahalline azimet etmişlerdir. Urla'dan bir heyeti askeriye hadise mahalline gelmiş tetkikat ve tahkikat icra eylemişlerdir. İzmir'e muvasala eden Kumandan Fuat Paşa Hazretleri faciayı haber alınca mütessiren derhal geri hareket etmiştir. Sabahleyin facia şehrimizde şayi’a olur olmaz umumi bir teessürle karşılanmıștır. Merhum Nihat ve Zeki Beylerin ikisi de aile sahibidir. Nihat beyin aileleri şehrimizde bulunduğu gibi Zeki Beyin refikalarının da dün akşam şehrimize muvasalatına intizar olunuyordu.

Sabahleyin erkenden Nihat ve Zeki Beyin iaşeleri askerî hastanesine getirilmiş ve öğleden sonra saat 16.00 'da bütün şehri matemlere boğan hazim ve muazzam bir cenaze alayı ile medafin-i ebediyyelerine nakil olunmuştur.

Anadolu, Zeki ve Nihat Bey gibi kıymetli iki şahsiyetini kaybetmiş olan büyük ordumuza ve merhumların bütün silah arkadaşlarına ve hepimizden daha fazla muhtac-1 teselliye.

Ek 14. Ahenk gazetesindeki haberin günümüz alfabesine çevrilmiş hali 16 Temmuz 1928. 


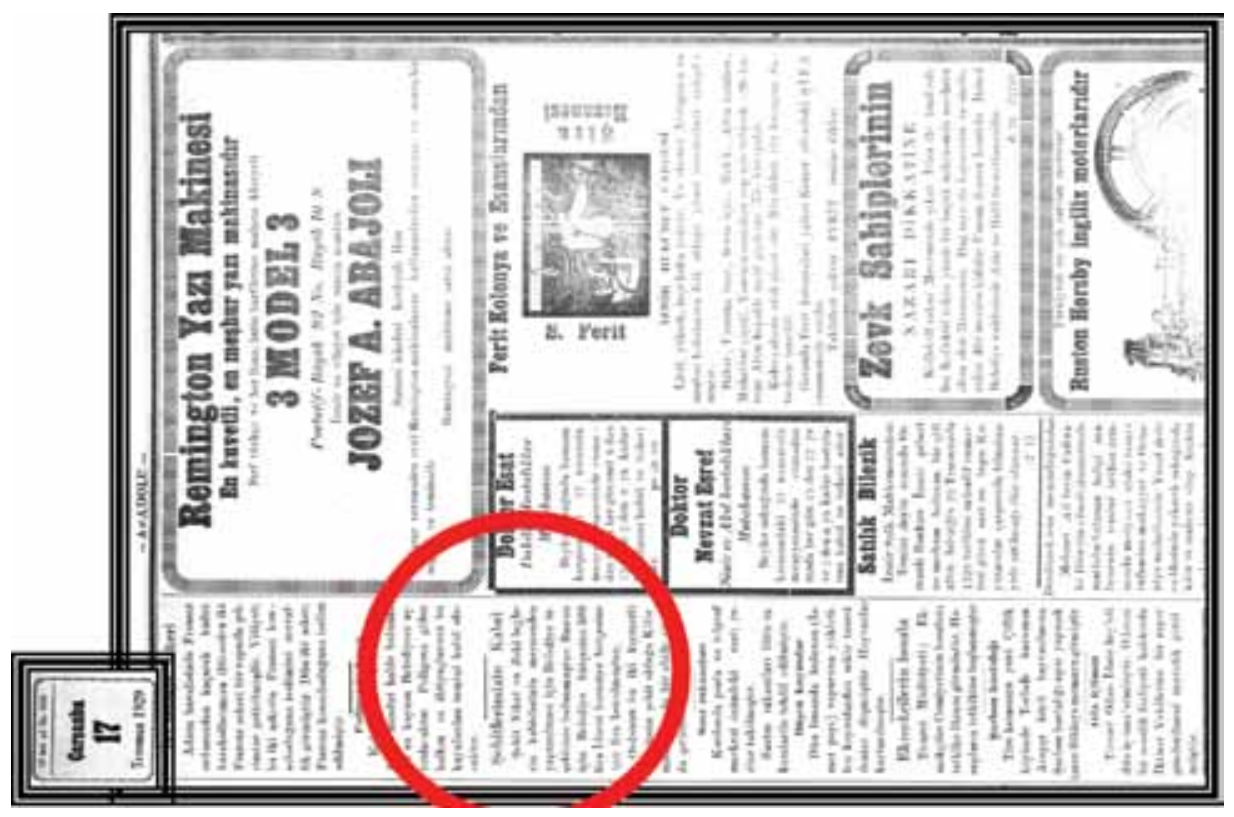

Ek 15. İzmir yerel gazetelerinde Bursalı Yarbay Nihat Bey'in mezarının mermerden yapılması ile ilgili çıkan haber Anadolu gazetesi, 17 Temmuz 1929.

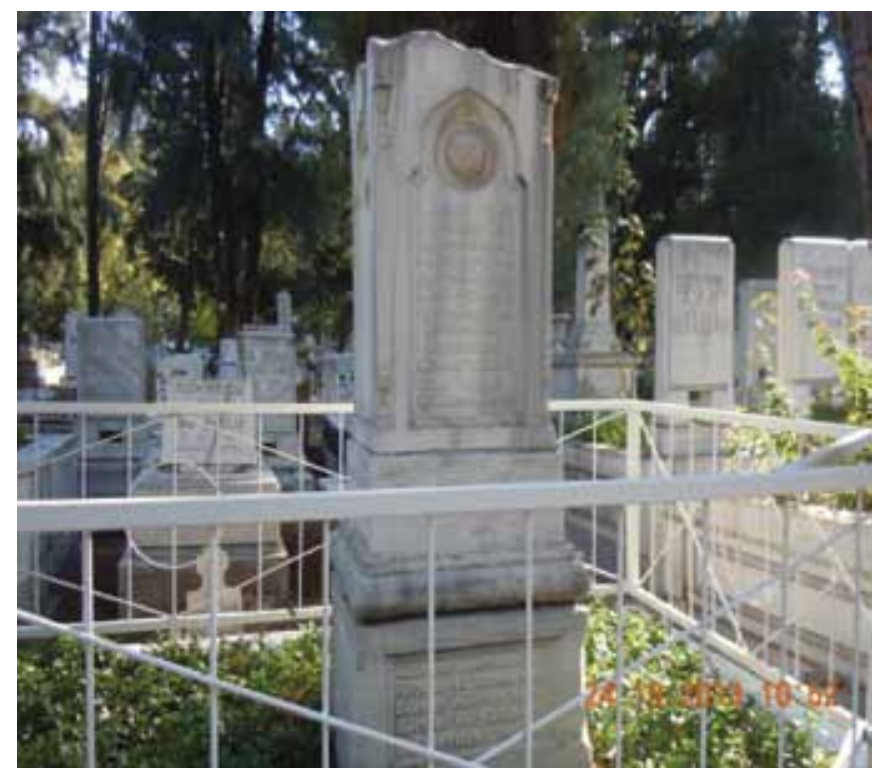

Ek 16. Kokluca Mezarlığı'nda Bursalı Mehmet Nihat Bey’in mezarı Bornova/İzmir 24 Ekim 2013 


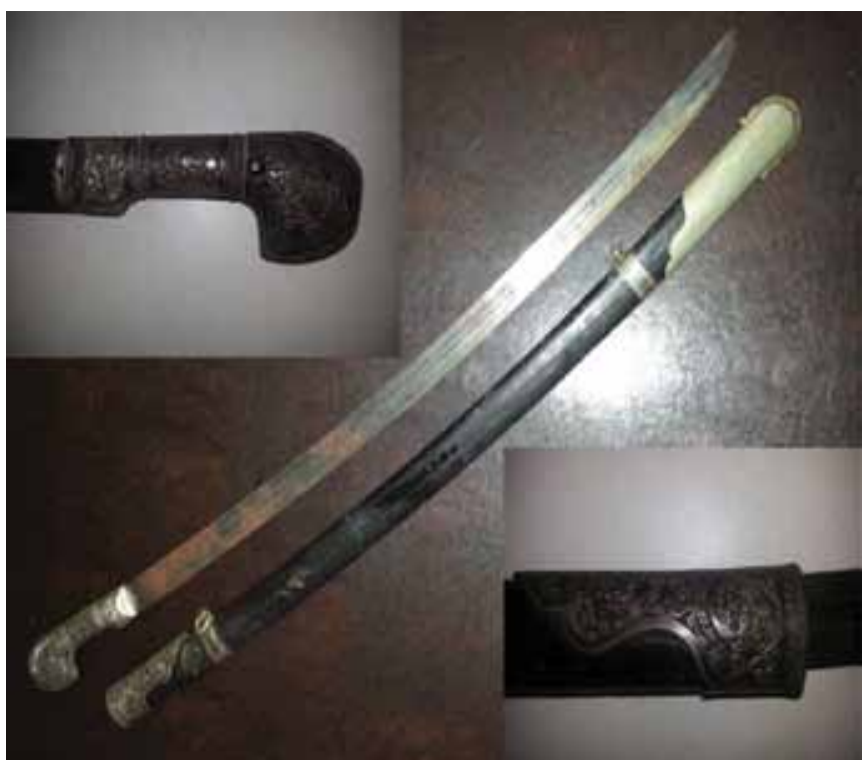

Ek 17. Bursalı Mehmet Nihat Bey’in kılıcı Urla/İzmir, 16 Ocak 2014

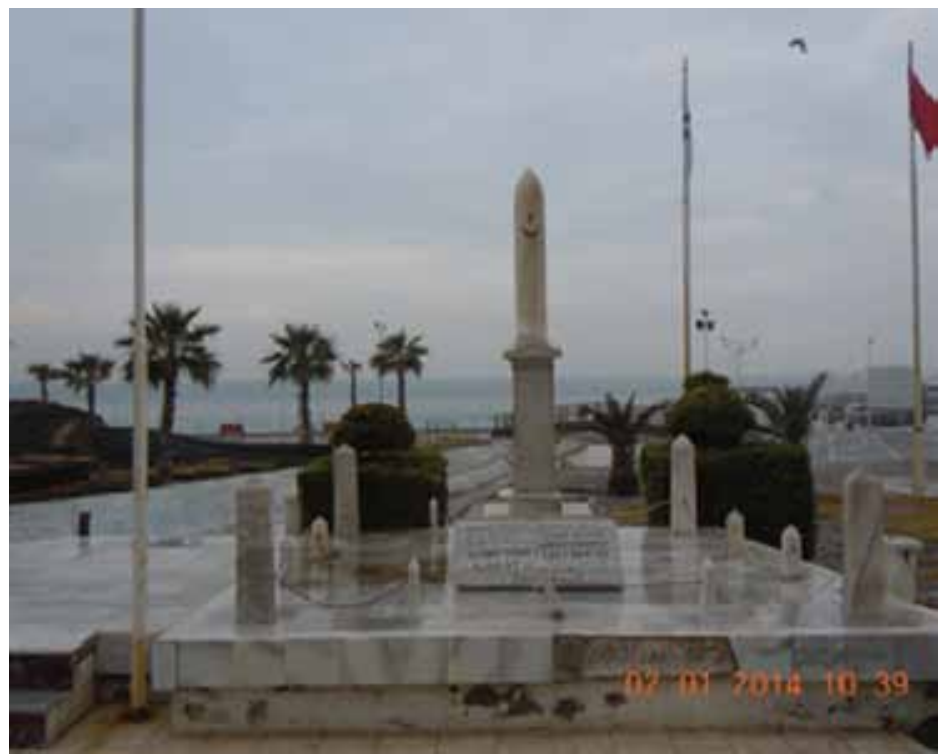

Ek 18. Bursalı Yarbay Mehmet Nihat Bey ile Yarbay Çobanoğlu Zeki Bey’in Güzelbahçe'de şehit düştükleri yerde yapılan anıt. 


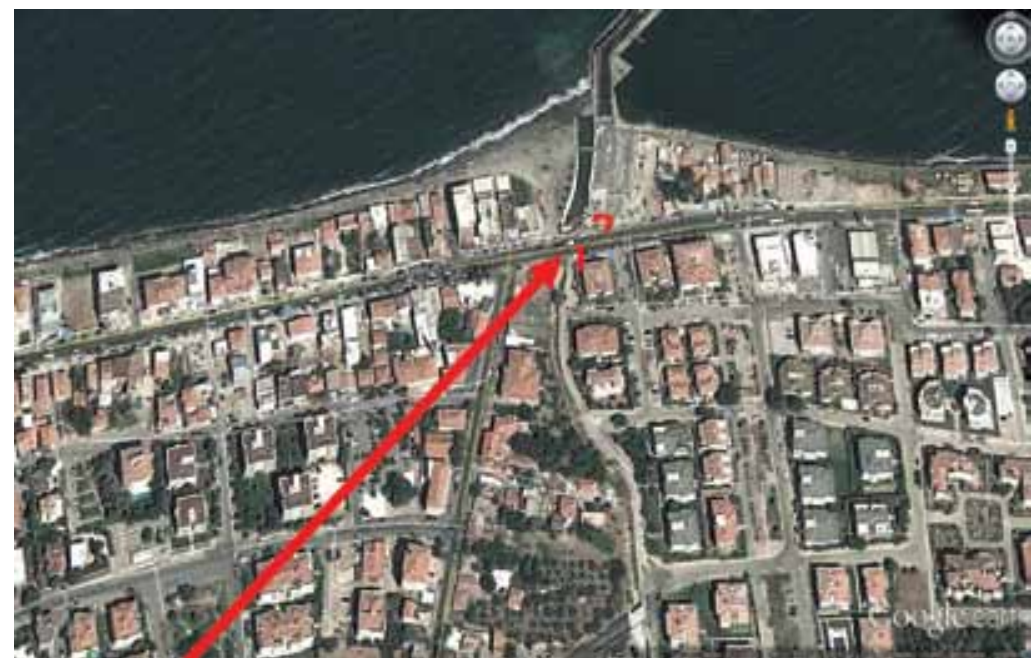

Ek 19. 1- Bursalı Yarbay Mehmet Nihat Bey ile Yarbay Çobanoğlu Ömer Zeki Bey'in şehit düştükleri yer, 2- Güzelbahçe'de șehit düştükleri yerin karşısına yapilan anit.

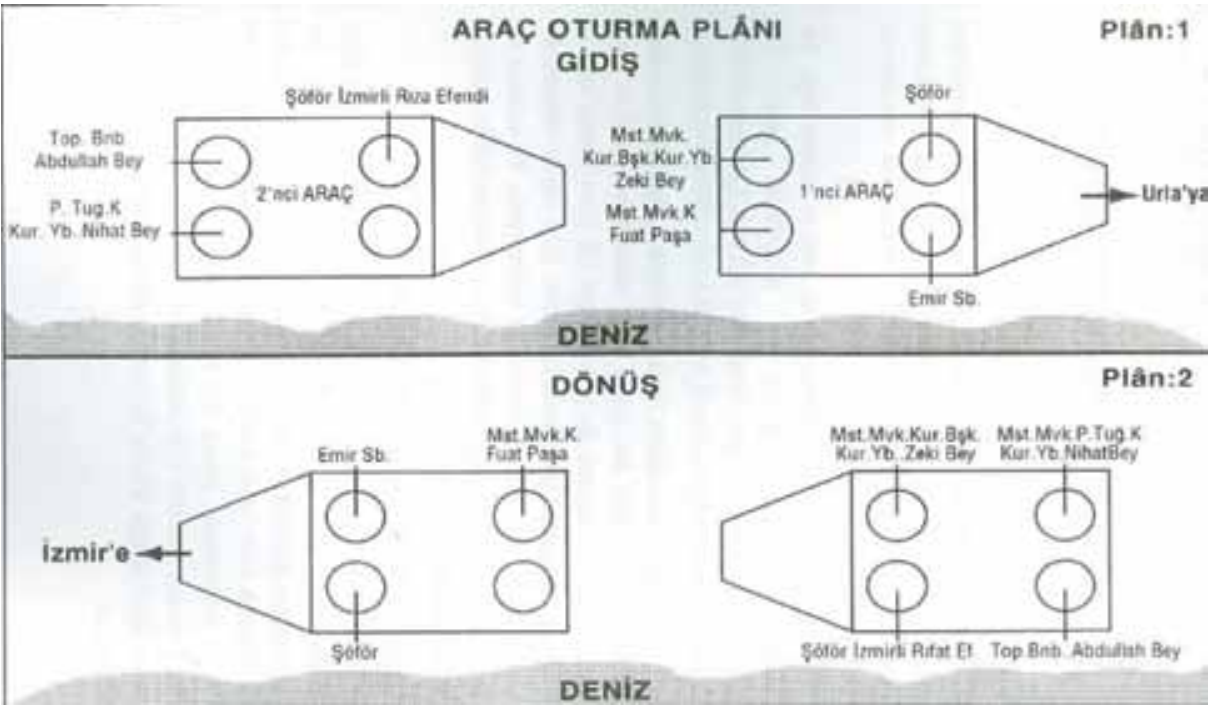

Ek 20. Bursalı Mehmet Nihat Bey'in şehit olduğu gün otomobildekiler ve oturdukları yerleri gösteren kroki 

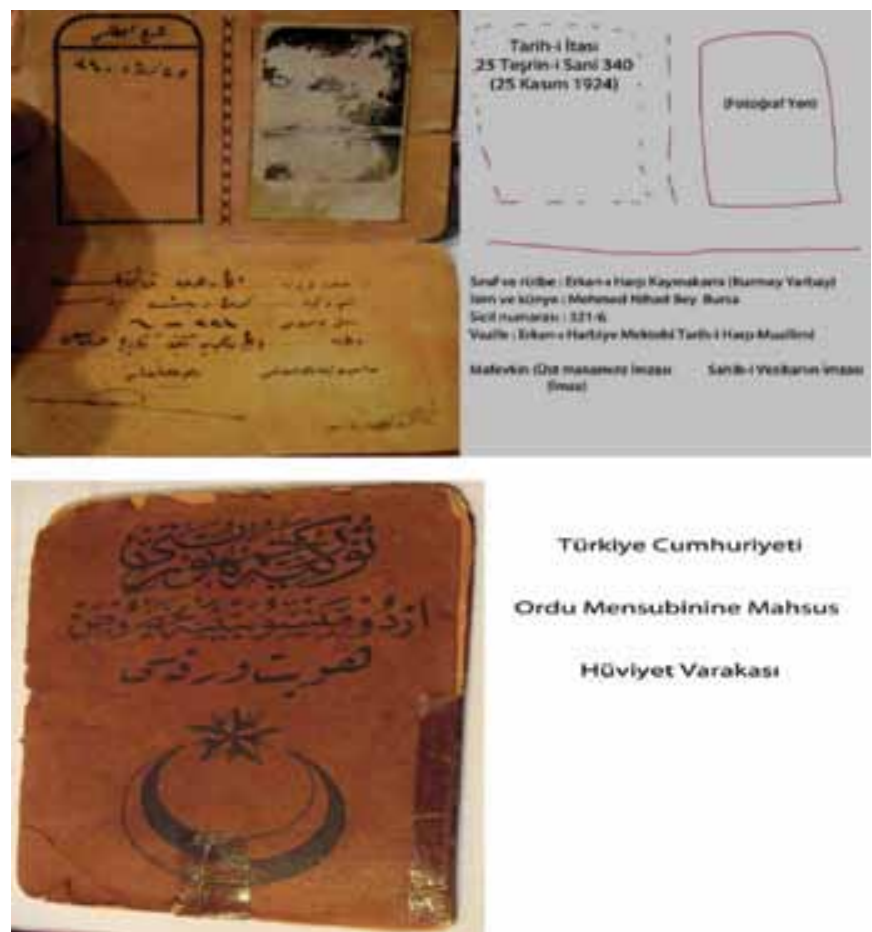

Torkiye Cumhuriyeti

Ordu Mensubinine Mahsus

Hovlyet Varakası

Ek 21. Bursalı Mehmet Nihat Bey'den torunu Munis KİRIZMAN'a kalan askerî kimlik kartı

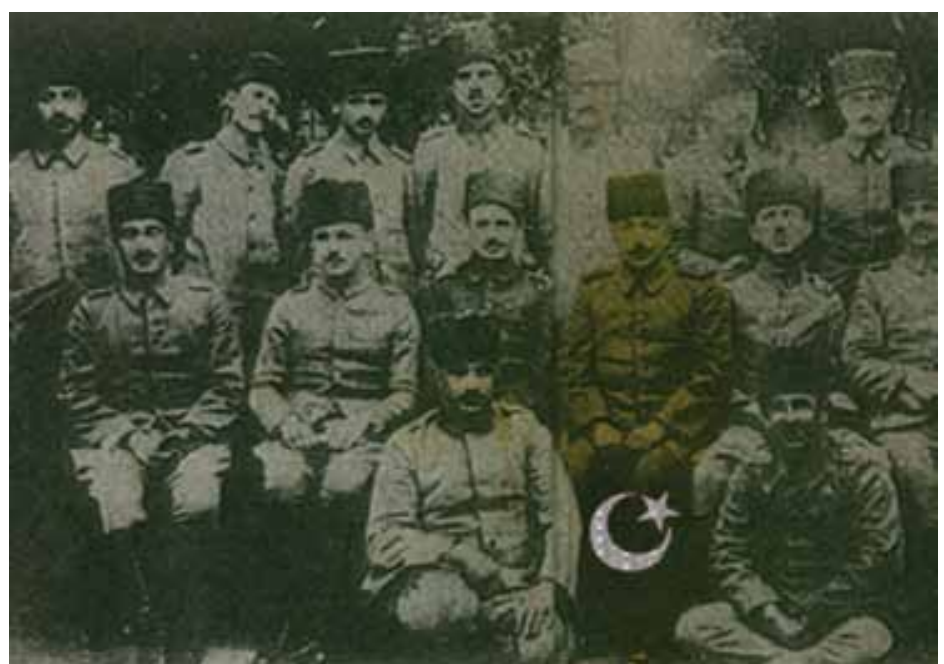

Ek 22. Bursalı Mehmet Nihat Bey (ay yıldızlı) ve Kurtuluş Savaşı’nda Büyük Taarruz'a katilan subaylar 1922 